\title{
Life Cycle Assessment of European anchovy (Engraulis encrasicolus) landed by purse seine vessels in northern Spain
}

Jara Laso $^{1, *}$, Ian Vázquez-Rowe ${ }^{2}$, María Margallo${ }^{1}$, Rosa M. Crujeiras ${ }^{3}$, Ángel Irabien ${ }^{1}$, Rubén Aldaco ${ }^{1}$

${ }^{1}$ Department of Chemical and Biomolecular Engineering, University of Cantabria, Avda. de los Castros s/n, 39005, Santander, Spain

${ }^{2}$ Peruvian LCA Network, Department of Engineering, Pontificia Universidad Católica del Perú, Av. Universitaria 1801, San Miguel, Lima, Peru

${ }^{3}$ Department of Statistics, Mathematical Analysis and Optimization, Faculty of Mathematics, Universidade de Santiago de Compostela, Campus Sur s/n, C.P. 15782, Santiago de Compostela, Spain

*Corresponding author: Jara Laso. E-mail: jara.laso@unican.es

\section{Abstract}

Purpose The main purpose of this article is to assess the environmental impacts associated with the fishing operations related to European anchovy fishing in Cantabria (Northern Spain) under a life cycle approach.

Methods The Life Cycle Assessment (LCA) methodology was applied for this case study including construction, maintenance, use and end of life of the vessels. The functional unit used was $1 \mathrm{~kg}$ of landed round anchovy at port. Inventory data were collected for the main inputs and outputs of 32 vessels, representing a majority of vessels in the fleet.

Results and discussion Results indicated, in a similar line to what is reported in the literature, that the production, transportation and use of diesel were the main environmental hotspots in conventional impact categories. Moreover, in this case, the production and transportation of seine nets was also relevant. Impacts linked to greenhouse gas (GHG) emissions suggest that emissions were in the upper range for fishing species captured with seine nets and the value of Global Warming Potential (GWP) was $1.44 \mathrm{~kg} \mathrm{CO}_{2}$ eq per functional unit. The ecotoxicity impacts were mainly due to the emissions of anti-fouling substances to the ocean. Regarding fisheryspecific categories, many were discarded given the lack of detailed stock assessments for this fishery. Hence, only the Biotic Resource Use category was computed, demonstrating that the ecosystems' effort to sustain the fishery is relatively low.

Conclusions The use of the LCA methodology allowed identifying the main environmental hotspots of the purse seining fleet targeting European anchovy in Cantabria. Individualized results per port or per vessel suggested that there are significant differences in GHG emissions between groups. In addition, fuel use is high when compared to similar fisheries. Therefore, research needs to be undertaken to identify why fuel use is so high, particularly if 
it is related to biomass and fisheries management or if skipper decisions could play a role.

Keywords: Engraulis encrasicolus; fuel efficiency; industrial ecology; Life Cycle Assessment; pelagic fisheries; purse seining

\section{Introduction}

Seafood is increasingly recognized as playing an important role in terms of food supply and security worldwide. In fact, the food versus feed debate is also highly related to capture fisheries given the dilemma of destining dwindling landings to direct or indirect human consumption (Fréon et al. 2014c). The beneficial effect of fish consumption on human health has been related to the high content of n-3 fatty acids, and it has been a recurring policy strategy to foster direct human consumption (Zlatanos and Laskaridis 2007). In this context, according to Zlatanos and Sagredos (1993), anchovy species are among the best sources of n-3 fatty acids.

European anchovy (Engraulis encrasicolus, Linnaeus, 1758) is a pelagic species belonging to the Engraulidae family. It is distributed along the Atlantic continental shelves of Europe and Africa, into the Mediterranean, Adriatic and Aegean seas and further into the Black Sea. It is a short-lived species, with individuals generally living between 3 and 5 years. Hence, population levels depend strongly on the incoming year-class strength, which is highly variable and largely dependent on environmental factors (Fréon et al. 2005).

Two different fleets fish for European anchovy in the Bay of Biscay, although they are spatially and temporally well separated. On the one hand, Spanish fleets operate mainly in Divisions VIIIc and VIIIb in the spring (Figure 1). On the other hand, French vessels operate in Division VIIIa in summer and autumn and in Division VIIIb in winter and summer (Pontes et al. 2015). Among all the existing fleets that target European anchovy, the purse seining fleet based in the region of Cantabria (Northern Spain) is the main anchovy catching fleet in the Bay of Biscay. In this context, anchovy represents the fifth most consumed seafood species in Spain, and the second most preferred in Cantabrian households (Eurofish 2012). 


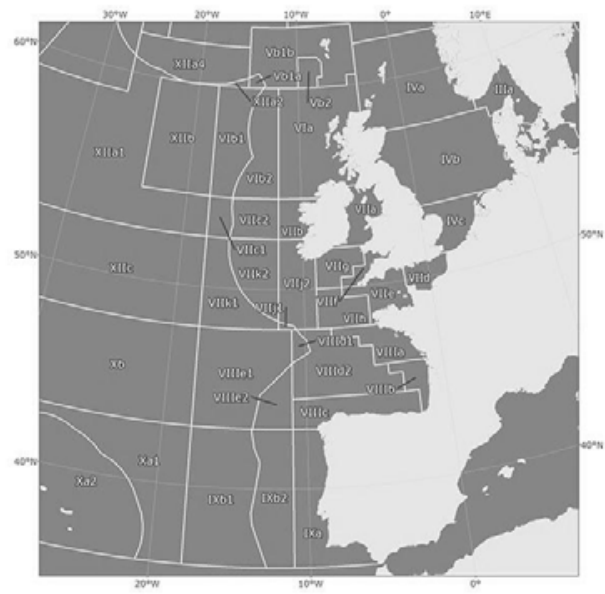

Figure 1. Geographical boundaries of the International Council for the Exploration of the Sea (ICES) subdivisions IV-VIII (Source: FAO, 2016).

The Spanish European anchovy fishery developed rapidly in the 1950s and began its decline in the early 1970s until the mid-1980s, when the French fishery developed (Villamor and Abaunza 2009). A couple of decades later, at the start of the new millennium, the fishery started to fail due to poor recruitment (Pontes et al. 2015). In fact, the fishery was closed on July $1^{\text {st }} 2005$ and reopened in 2006, but it was closed again in 2007 until the end of 2009. The fishery has remained open since June 2010 thanks to improved stock performance in the past few years (Pontes et al. 2015).

Cantabria is a small coastal region in the North of Spain where fishing and processing of anchovy is one of the main economic revenues in the food industry representing approximately 2\% of Cantabria's Gross Domestic Product (GDP) (Ministry of Agriculture, Food and Environment 2015). Anchovy fishing operations started in the 1900s and reached peak captures in 1965 (82,000 metric tons) to decline dramatically in the 1970s and 80s due to overexploitation (García-Cobo 1998). Figure 2 shows anchovy captures from 2006 to 2015 by Cantabrian purse seining vessels. As shown, anchovy landings in 2006, when the fishery was closed, were very low. However, once the fishery reopened in 2010, the amount of anchovy landed and its economic value fluctuated to reach its highest value in 2015, with almost 6700 metric tons of anchovy landed in Cantabrian ports generating economic revenue of approximately 13 million euros at first sale. 


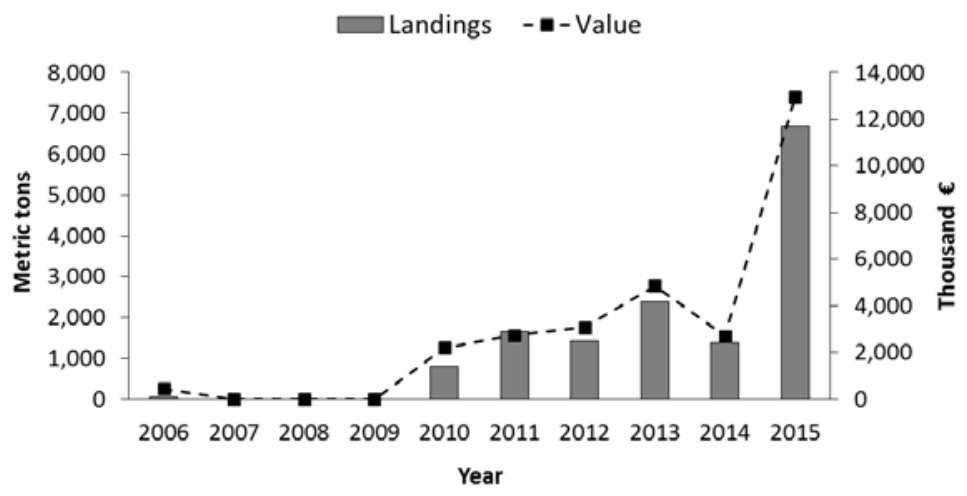

Figure 2. Anchovy landings in Cantabria ports and economic value in the period 2006-2015 (Data adapted from the Cantabrian Institute of Statics (ICANE). Grey bar represents anchovy captures and the dark points the value of these captures in thousands of $€$.

Approximately half of the anchovy landed in Cantabria is consumed fresh. The remaining $50 \%$ goes to factories where $25 \%$ is salted and the final $25 \%$ is canned (Magrama 2013). In fact, in Cantabria there are approximately 70 anchovy canning companies. In 2012, 13,267 ${ }^{1}$ metric tons of canned anchovies were produced, which translates into economic revenue that adds up to more than 91 million $€$. Moreover, the quality of the Cantabrian canned anchovy is world-renowned and it is considered a "gourmet product" by consumers due to its handmade and traditional manufacture (Laso et al. 2016b).

Despite the critical overexploitation of the European anchovy fishery, no environmental assessment of the industrial operations of this fleet exists in the literature. Although the direct link between an overexploited stock and the assessment of other environmental impacts may not be evident to the common public, recent studies have demonstrated that stock rebuilding can have an important role in fuel efficiency, which is usually the main carrier of GHG emissions and other environmental impact in fishing fleets (Ziegler and Hornborg, 2014; Parker et al., 2015). In this context, Life Cycle Assessment (LCA), a standardized framework used to quantify resource use and a broad set of environmental impacts of products through their supply chain (ISO 2006a and 2006b), is considered a consensus method to evaluate this sort of environmental impacts. In fact, the use of LCA as a method to quantify environmental impacts of seafood production systems has emerged rapidly over the 2000-2016 period (Ziegler et al. 2016). A comprehensive LCA of the Cantabrian anchovy fishery would be useful to complement

${ }^{1}$ It should be noted that the region imports substantial amounts of European anchovy from other Spanish regions, France or Morocco, and other anchovy species from Peru (Engraulis ringens) and Argentine (Engraulis anchoita) to nourish the canning industry. 
the recent studies regarding the processing of canned anchovies, as well as the management of anchovy residues throughout the canning process (Laso et al. 2016a, 2016b), as well as those linked to stock management (Pontes et al. 2015).

Previous fishery LCA studies, including studies of purse seining fisheries in the North Atlantic, have shown that conventional impact categories were heavily associated with fuel combustion in the fishery (VázquezRowe et al. 2010; Ramos et al. 2011; Almeida et al. 2014). Studies for other similar pelagic fisheries elsewhere, such as Peruvian anchoveta, were recently developed by Avadí (2014a, 2014b, 2015) and Fréon (2014a, 2014b, 2014c). Hence, this study aims to evaluate the environmental impacts of the Cantabrian purse seining fishery for European anchovy for one year of operation (i.e., 2015). The LCA methodology was applied to quantify the overall environmental impact of the fishery. Although the study was not extended to other years of operation to assess the effect of stock size on environmental impacts due to lack of historical data, a statistical analysis was computed to analyze the variability of environmental impacts between vessels and ports.

\section{Materials and Methods}

\subsection{Goal and scope definition}

The environmental analysis was based on LCA methodology and assumptions, following ISO 14040 specification. Moreover, the sampling of the purse seining vessels fulfilled PAS 2050-2 (PAS 2050-2, 2012) requirements specific to seafood and other aquatic food products.

The goal of this LCA study was to assess the environmental impacts associated with the fishing activity of European anchovy landings by the Cantabrian purse seining fleet. The functional unit (FU) considered was 1 kg of landed round anchovy by Cantabrian purse seining vessels in year 2015, reflecting the function of delivering raw material for further processing in local canning industries.

The system under study comprised the phases of a vessel's life cycle: construction, use, maintenance and end of life (EoL), including hull and engine production, diesel consumption, antifouling and lubricant oil emissions, net and boat paint production and vessel dismantling, as observed in Figure 3. Crew impact was limited to the emissions onboard (solid waste and wastewater), but excluding provision of food and transport (Fréon et al. 2014b). This assessment constituted a so-called cradle-to-gate study for the product (i.e., European anchovy) and a cradle-to-grave study for the main carrier of the fishing operations: the fishing vessels (Guinée et al. 2001). Landing operations at port were excluded from the system boundary (see Figure 3), as well as a series of biological issues, such as seafloor use, given that their consideration involves impact categories that are not fully developed in current LCA methodology (Vázquez-Rowe et al. 2012c). Moreover, electronic devices were excluded from the 


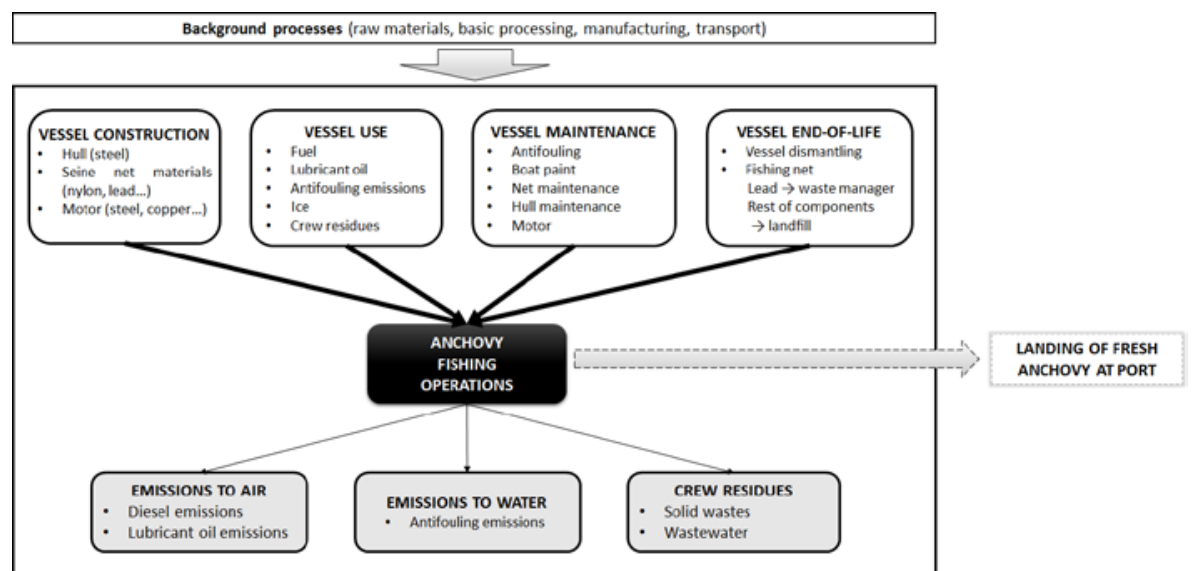

Figure 3. System boundary for the anchovy fishing fleet. Elements with dotted lines were excluded from the boundary.

\subsection{Co-product allocation}

The Cantabrian purse seining fleet performs its activities in a multispecies fishery. Therefore, direct and indirect inputs and outputs of the fishing operations, as well as the resulting environmental burdens, need to be allocated between European anchovy and the remaining landed by-catch (Ayer et al. 2007). In addition to European anchovy, the Cantabrian fleet catches tuna species (mainly Thunnus alalunga), European pilchard (Sardina pilchardus), Atlantic mackerel (Scomber scombrus) and Atlantic horse mackerel (Trachurus trachurus). For this particular study, three types of allocation were evaluated: mass, economic and energy (see Table 1 for details). No major differences between the three types of allocation were observed for the case of European anchovy, representing in all scenarios approximately $45 \%$ of total landings of the fleet. However, economic allocation was discarded based on the fact that landing sale prices in Galicia, a neighboring region in northern Spain, were used for the same period to compute this approach due to the lack of regional data (Xunta de Galicia 2016). Although the values could be used as a proxy of the situation in Cantabria, since landings in different Spanish regions tend to be influenced by common economic drivers (i.e., common geographic zone, common wholesales, common economic patterns), we were unable to determine the uncertainty behind this estimation. Similarly, although tuna is a large pelagic species which is usually sold at a much higher price, its landings are concentrated in a very specific window of time towards the end of the summer and beginning of the autumn months. Therefore, it is unlikely that seiners will target tuna species rather than small-pelagics throughout most 
of the year. Energy is another repeatedly used allocation perspective that has been traditionally applied in seafood LCA studies (Ayer et al. 2007; Pelletier and Tyedmers 2011). In fact, Pelletier and Tyedmers (2011) defend that seafood products are landed and processed based on a need to fulfil the human need for a minimum caloric intake and, therefore, the use of energy allocation constitutes a relationship that is causal from a biophysical and social perspective. However, based on the fact that the system boundaries were limited to the landing of the fish at port in this particular study, mass allocation was chosen as the most appropriate approach context since it is considered to better reflect reality over longer time periods and changing economic conditions and constitutes a clearer perspective to communicate to the stakeholders in this first stage of the supply chain.

Table 1. Mass, economic and energy allocation factors for the anchovy fishing fleet. Landings represent the average value in 2015.

\begin{tabular}{|c|c|c|c|c|c|c|c|}
\hline \multirow[b]{2}{*}{ Species } & \multicolumn{2}{|c|}{ Landings } & \multirow{2}{*}{$\begin{array}{l}\text { Mass } \\
\text { allocation }\end{array}$} & \multirow{2}{*}{$\begin{array}{c}\text { Value } \\
(€ / \mathbf{k g}) \\
(1)\end{array}$} & \multirow{2}{*}{$\begin{array}{l}\text { Economic } \\
\text { allocation }\end{array}$} & \multirow{2}{*}{$\begin{array}{c}\text { Energy } \\
(\mathbf{M J} / \mathbf{k g}) \\
(2)\end{array}$} & \multirow{2}{*}{$\begin{array}{l}\text { Energy } \\
\text { allocation }\end{array}$} \\
\hline & $\begin{array}{l}\text { Mass } \\
(\mathrm{kg})\end{array}$ & SD & & & & & \\
\hline European anchovy & 196,634 & $\pm 103,634$ & $43.5 \%$ & 1.54 & $44.3 \%$ & 2.18 & $45.9 \%$ \\
\hline Tuna (Thunnus spp.) & 9,938 & $\pm 42,157$ & $2.2 \%$ & 4.09 & $6.0 \%$ & 2.42 & $2.6 \%$ \\
\hline European pilchard & 110,563 & $\pm 89,560$ & $24.5 \%$ & 2.11 & $34.2 \%$ & 2.11 & $24.9 \%$ \\
\hline Atlantic mackerel & 51,188 & $\pm 12,545$ & $11.3 \%$ & 0.70 & $5.2 \%$ & 2.05 & $11.2 \%$ \\
\hline $\begin{array}{l}\text { Atlantic horse } \\
\text { mackerel }\end{array}$ & 83,353 & $\pm 103,240$ & $18.5 \%$ & 0.84 & $10.3 \%$ & 1.72 & $15.4 \%$ \\
\hline \multicolumn{8}{|c|}{$\begin{array}{l}\text { (1) } \\
\text { (2) }\end{array}$} \\
\hline 2.3. Data acquisit & & & & & & & \\
\hline
\end{tabular}

Data were collected for year 2015 for a sample of 32 purse seining vessels out of a total of 41 belonging to the Cantabrian fishing fleet. These vessels represented $78 \%$ of this fleet, which allowed meeting the requirements recommended in the PAS 2050 document in terms of sample representativeness of vessels in a particular fleet (PAS 2050-2 2012). The percentage represents the number of fishing vessels that provided data for the study. Questionnaires on operational aspects and capital goods of the purse seine vessels were delivered to all skippers of the 41 vessels; therefore, the sample size also represents the response rate obtained. An average lifespan for each vessel of 30 years was considered (SUPERPROP 2012).

Primary data for fishing vessel operations were obtained from questionnaires filled out by skippers from the seven main purse seining ports in Cantabria: Colindres (P1), Santoña (P2), San Vicente de la Barquera (P3), Comillas (P4), Laredo (P5), Santander (P6) and Castro Urdiales (P7) (see Figure 4 for their geographical 
distribution). Vessel-specific data requested included the overall length, gross tonnage, vessel width, number of engines and their propulsive power, hull material and life span. For each vessel, operational data requested included the type and amount of fuel used, net consumption and dimensions, ice, lubricant oil, anti-fouling and paint, days at sea, crew size and annual catch data.

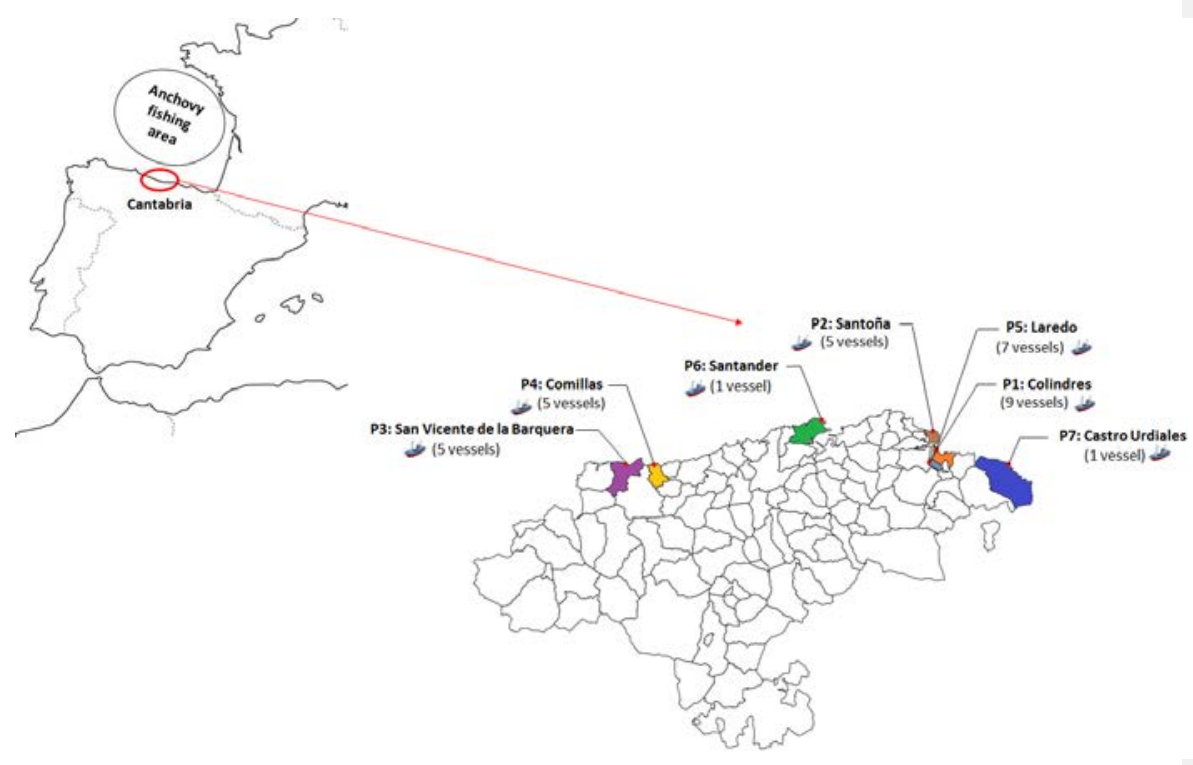

Figure 4. European anchovy fishing zone and Cantabrian ports.

Anti-fouling and paint were considered important in this study for two reasons: they tend to be linked to toxicity impact categories (Hospido and Tyedmers 2005) and skippers reported sending their vessels to the docks for maintenance once per year. The composition of the main paints and anti-fouling agents, as well as the emissions related to their production, was included in the inventory. These data were obtained from a leading world producer.

The production, transport and consumption of the seine nets were included within the system boundary due to the important percentage they represent in the total weight of the fishing vessels (Fréon et al. 2014b). Skippers reported that the production of nylon nets has shifted through the past years from Spain, which currently produces approximately $20 \%$ of total nets, to Portugal (20\%) and the Philippines (60\%). The composition of the nets was made up of nylon (50\%), lead (28\%), ethylene vinyl acetate (EVA) (20\%) and polysteel (2\%). These materials were produced in Canada, Valencia (Spain), Korea and Alicante (Spain), respectively, according to data reported by local retailers. Therefore, there has been an increase in transport that will be taken into account in this 
study as compared to previous studies in the literature (Vázquez-Rowe et al., 2010). Moreover, it was considered that the lifespan of seine nets was roughly 5 years. However, partial repairs are done annually, renewing at least 25\% on an annual basis due to net losses at sea (Vázquez-Rowe et al. 2010). Another important operational input, ice, was produced at an ice-making factory. For this, data were obtained from a factory in Colindres, one of the fishing ports in the current study, which produced 2,000 metric tons per year. The factory reported using ammonia as the cooling agent in its operations.

Regarding vessel construction, only those impacts associated with the steel used in vessel hulls and engines were quantified. To estimate the weight of each vessel, the Light Ship Weight (LSW) as described by Freón et al. 2014b was used (Eq 1):

$L S W($ metric ton $)=-263.81+0.57 \cdot$ holding capacity $+43.77 \cdot$ width

To apply this correlation, the holding capacity and the width data reported by the interviewed skippers were used. LSW is based on several statistical models that use the holding capacity and physical dimensions of the Peruvian vessels. Fréon and colleagues (2014b) found a high correlation between LSW and the following variables: holding capacity $\left(\mathrm{m}^{3}\right)$, gross tonnage (GT) (unitless index), length and height (m). However, collinearity was found between length and height. Moreover, GT was also excluded from the variables due to the high number of missing values. Scatter plots of LSW versus each of the tested variables showed linearity, which justifies the use of a linear model being the best regression equation (adjusted $r^{2}=0.79$ ) used in this work. It was considered that this correlation was valid for Spanish fleet due to the similarity in terms of holding capacity. Approximately $80 \%$ of the LSW value was assumed to correspond to the weight of the hull (steel), while $20 \%$ corresponded to the weight of structural elements and other systems that were not considered in this analysis. Moreover, it was assumed that $12 \%$ of the hull was replaced every two years for maintenance purposes (Fréon at al. 2014b).

The weight of the main and auxiliary engines was obtained from a leading world producer according to the power data facilitated by skippers (Guascor 2016). The composition modelled for these engines considered $65 \%$ cast iron, $34 \%$ chrome steel and $1 \%$ white metal alloys $\left(\mathrm{AlCuMg}_{2}\right)$, and they were replaced once over the lifetime of the vessel (Fréon et al. 2014b). It was assumed that 50\% of the steel used in vessel hulls and engines was recycled. This assumption was based on data from the European Steel Association (Eurofer), which stated that $50 \%$ of the steel in the market was secondary steel (Bala et al. 2015). 
Background data regarding the production of diesel fuel were obtained from the ecoinvent ${ }^{\circledR} \mathrm{v} 3.1$ database (Ecoinvent 2016). The process data for diesel production include oil field exploration, crude oil production, long distance transportation, oil refining, regional distribution, etc. Additional processes where no direct data were available are linked to the production of supply materials, such as materials for vessel construction, seine nets, anti-fouling, paint and lubricant oil agents and electricity. To improve data quality and consider local conditions, the electricity mix provided by the ecoinvent ${ }^{\circledR}$ database was adapted to the characteristics of the Spanish electricity mix of 2013 (Vázquez-Rowe et al. 2015) for those processes occurring in Spanish territory. Finally, processes linked to the management of crew residues and fishing activity wastes, as well as the EoL of the vessel, were also taken from the ecoinvent ${ }^{\circledR}$ database.

\subsubsection{Un-monitored emissions}

The emissions of carbon dioxide $\left(\mathrm{CO}_{2}\right)$ resulting from fuel combustion were calculated on the base of the EMEP-Corinair Emission Inventory Handbook of 2006 (EMEP-Corinair 2006), while remaining emissions, such as nitrogen oxides $\left(\mathrm{NO}_{\mathrm{x}}\right)$, carbon monoxide $(\mathrm{CO})$ and sulphur oxides $\left(\mathrm{SO}_{\mathrm{x}}\right)$ were calculated on the base of the revised version of the handbook in 2013 (EMEP/EEA 2013). It is important to point out that, in the current study, $\mathrm{CO}_{2}$ emissions resulting from the use of lubricant oil were considered and calculated on the base of the IPCC Guidelines for National Greenhouse Gas Inventories (IPCC 2006), as shown in the following equation:

$\mathrm{CO} 2$ emissions $=\mathrm{LC} \cdot$ CClubricant $\cdot$ ODUlubricant $\cdot 44 / 12$

where LC was the total lubricant consumption (TJ), CClubricant was the carbon content of lubricants (20 metric tons C/TJ), ODU lubricant was the Oxidised During Use factor (0.2) and 44/12 was the mass ratio of $\mathrm{CO}_{2} / \mathrm{C}$. The loss of paint and anti-fouling to the marine environment was set as two thirds of the total employed, as assumed by Hospido and Tyedmers (2005). Finally, the environmental impacts linked to crew activities were modelled considering the number of crew members. Thereafter, the procedure identified by Fréon et al. 2014, which established that $120 \mathrm{~L}$ of wastewater is produced per crew member per working day and $0.2 \mathrm{~kg}$ of solid waste is generated per landed metric ton of fish, was followed. Approximately 38\% of these solid residues were hazardous waste (mostly rags impregnated with lubricant oil), 26\% plastic packaging, 20\% other rags, 10\% paper and 6\% organic matter. In this study, it was considered that the hazardous wastes were deposited underground in a specialized landfill, whereas the non-hazardous wastes were deposited in a municipal landfill. Moreover, according to recycling data from Ecoembes, in Cantabria, $21 \%$ of the total plastic and $43 \%$ of the total paper was recycled in 2015 (Ecoembes 2015). The remaining residues, together with the organic matter, were assumed to be incinerated (Plan de Residuos de Cantabria, 2016). Finally, it was assumed that wastewater was collected and sent 
to a municipal wastewater treatment plant (WWTP). Data on the WWTP were obtained from Lorenzo-Toja et al. (2015). The selected plant was the WWTP from Ortigueira (Galicia) assuming that its technical and physical characteristics were similar to Cantabrian WWTPs.

\subsection{Life Cycle Inventory}

According to the questionnaires obtained, the 32 purse seining vessels landed a total of 14,454 metric tons of fresh fish, with European anchovy being the most captured species (6,292 metric tons). The average allocated inventory data are shown in Tables 2 and 3.

Table 2. Inputs for European anchovy landed in Cantabrian ports by purse seiners (data reported per functional unit: $1 \mathrm{~kg}$ of landed round anchovy in a Cantabrian port in year 2015).

\begin{tabular}{|c|c|c|c|}
\hline \multicolumn{4}{|l|}{ Inputs (from the technosphere) } \\
\hline \multicolumn{4}{|l|}{ Construction } \\
\hline Materials and fuels & Unit & Value & SD \\
\hline Steel (hull) & g & 10.56 & \pm 3.43 \\
\hline Cast iron (motor) & g & 0.336 & \pm 0.139 \\
\hline Chrome steel (motor) & g & 0.178 & \pm 0.075 \\
\hline Aluminium alloy ( $\mathrm{AlCuMg}_{2}$ ) (motor) & g & 0.005 & \pm 0.002 \\
\hline Nylon (fishing net) & g & 5.172 & \pm 1.375 \\
\hline Lead (fishing net) & g & 5.143 & \pm 0.888 \\
\hline Ethylene Vinyl Acetate (EVA) (fishing net) & g & 2.128 & \pm 0.567 \\
\hline Polysteel (fishing net) & g & 0.456 & \pm 0.080 \\
\hline \multicolumn{4}{|l|}{ Use } \\
\hline Diesel & $\mathrm{kg}$ & 0.34 & \pm 0.14 \\
\hline Lubricant oil & g & 2.227 & \pm 0.788 \\
\hline Ice & $\mathrm{kg}$ & 0.388 & \pm 0.225 \\
\hline \multicolumn{4}{|c|}{ Maintenance (replenishment, fixtures or replacements) } \\
\hline Steel (hull) & g & 0.633 & \pm 0.206 \\
\hline
\end{tabular}




\begin{tabular}{lccc} 
Cast iron (motor) & $\mathrm{g}$ & 0.011 & \pm 0.004 \\
Chrome steel (motor) & $\mathrm{g}$ & $5.89 \cdot 10^{-3}$ & $\pm 2.21 \cdot 10^{-3}$ \\
Aluminium alloy (AlCuMg ) (motor) & $\mathrm{g}$ & $1.77 \cdot 10^{-4}$ & $\pm 7.08 \cdot 10^{-5}$ \\
Nylon (fishing net) & $\mathrm{g}$ & 2.327 & \pm 0.620 \\
Lead (fishing net) & $\mathrm{g}$ & 2.314 & \pm 0.255 \\
Ethylene Vinyl Acetate (EVA) (fishing net) & $\mathrm{g}$ & 0.957 & \pm 0.399 \\
Polysteel (fishing net) & $\mathrm{g}$ & 0.205 & \pm 0.035 \\
Anti-fouling & $\mathrm{g}$ & 1.747 & \pm 0.573 \\
Boat paint & $\mathrm{g}$ & 0.354 & \pm 0.117 \\
\hline End of life (includes recycling during maintenance phase) & & & \\
\hline Steel (hull and motor) & $\mathrm{g}$ & 11.38 & \pm 3.64 \\
Nylon (fishing net) & $\mathrm{g}$ & 7.499 & \pm 1.993 \\
Ethylene Vinyl Acetate (EVA) (fishing net) & $\mathrm{g}$ & 3.085 & \pm 1.432 \\
Polysteel (fishing net) & $\mathrm{g}$ & 0.661 & \pm 0.923 \\
Lead fishing net & $\mathrm{g}$ & 7.457 & \pm 0.930 \\
\hline
\end{tabular}

Table 3. Outputs for European anchovy landed in Cantabrian ports by purse seiners (data reported per functional unit: $1 \mathrm{~kg}$ of landed round anchovy in a Cantabrian port in year 2015).

\begin{tabular}{lcc}
\hline Outputs (to the technosphere) & & \\
\hline Product & Unit & Value \\
\hline European anchovy & $\mathrm{kg}$ & 1 \\
\hline Residues & Unit & Value \\
\hline Wastewater & $\mathrm{m}^{3}$ & $8.57 \cdot 10^{-4}$ \\
Hazardous wastes & $\mathrm{g}$ & 72.19 \\
Non-hazardous wastes & $\mathrm{g}$ & 37.99 \\
Plastic & $\mathrm{g}$ & 49.39 \\
Paper & $\mathrm{g}$ & 18.99
\end{tabular}




\begin{tabular}{lcc} 
Organic matter & $\mathrm{g}$ & 11.40 \\
\hline Outputs (to the environment) & & \\
\hline Emissions to the ocean & Unit & Value \\
\hline Zinc & $\mathrm{mg}$ & 281 \\
Copper & $\mathrm{mg}$ & 462 \\
Ethanol & $\mathrm{mg}$ & 17.50 \\
Ethyl-benzene & $\mathrm{mg}$ & 41.20 \\
Xylene & $\mathrm{mg}$ & 148 \\
4-Methyl-2-pentanone & $\mathrm{mg}$ & 19.40 \\
\hline Emissions to the atmosphere & $\mathrm{Unit}$ & Value \\
\hline $\mathrm{CO}_{2}$ (diesel and lubricant oil) & $\mathrm{kg}$ & 1.093 \\
$\mathrm{CO}^{(\text {diesel) }}$ & $\mathrm{g}$ & 2.550 \\
$\mathrm{SO}_{2}$ (diesel) & $\mathrm{g}$ & 11.90 \\
$\mathrm{SO}_{\mathrm{x}}($ diesel) & $\mathrm{g}$ & 6.890 \\
$\mathrm{NO}_{\mathrm{x}}$ (diesel) & $\mathrm{g}$ & 27.70 \\
$\mathrm{NMVOC}^{\text {(diesel) }}$ & $\mathrm{G}$ & 1.400 \\
\hline
\end{tabular}

\subsection{Life Cycle Impact Assessment}

The Life Cycle Impact Assessment phase was carried out using a mix of impact categories from different assessment methods. This rationale was followed in order to account for the most relevant conventional impact categories commonly used in LCA studies, following the recommendations provided by the Joint Research Centre of the European Commission (ILCD 2011, Hauschild et al. 2013), but also to account for less conventional marinerelated environmental impacts (Ziegler et al. 2016).

In the first place, the IPCC 2013 assessment method, 100-year time horizon, was used to compute the GHG emissions engendered by the analyzed production system (IPCC 2013). The reason for choosing this method is linked to the fact that it considers the most updated characterization factors for GHG emissions as recommended by the Intergovernmental Panel for Climate Change (IPCC 2013). Secondly, the CML-IA baseline method (Guinée et al. 2002) was selected to calculate acidification potential (AP) and eutrophication potential (EP). Thirdly, the ReCIPE midpoint (Goedkoop et al. 2009) was used to calculate impacts related to resource depletion: water depletion (WD), metal depletion (MD) and fossil depletion (FD). Particulate matter formation (PMF) and 
photochemical oxidant formation (POF) were also calculated using this assessment method. Finally, the USEtox method (Rosenbaum et al. 2008) was selected to calculate human and freshwater toxicity.

Regarding marine-related impact categories, the biotic resource use (BRU) impact category, as implemented by Parker (2011), was also used to monitor the primary production required (PPR) to sustain the European anchovy fishery (Pauly and Christensen 1995). The results were reported in terms of removed carbon. The selected unit to report PPR calculation was mass of carbon per live weight of fish ( $\mathrm{g} \mathrm{C} / \mathrm{kg}$ fish, wet weight). The mean trophic level (TL) selected for European anchovy was set at $3.1 \pm 0.45$ (Fishbase 2016; Vázquez-Rowe et al. 2012a).
$\mathrm{PPR}=[\mathrm{Catch} / 9] \times 10^{(\mathrm{TL}-1)}$
(Eq. 3)

Lost Potential Yield (LPY), as defined by Emanuelsson et al. 2014, was not applied due to the lack of two important parameters to compute this impact category: maximum sustainable yield (MSY) and fishing mortality ( $\left.\mathrm{F}_{\mathrm{MSY}}\right)$. However, the reports from ICES state that the limit reference point for spawning stock biomass ( $B_{\text {lim }}$ ) is widely overpassed ever since the fishery was reopened for fishing activities in 2010 (ICES, 2014). Other marine-related impact categories that have been presented in the literature, such as seabed disturbance (Ziegler et al. 2009), the Global Discard Index (Vázquez-Rowe et al. 2012) or other categories used to monitor overexploitation or biomass removal (Langlois et al. 2014, 2015; Woods et al. 2016), were also excluded from the scope of the study. Finally, the indicator edible protein energy return on investment (ep-EROI) was also calculated in this study. For the computation of the ep-EROI results, renewable and non-renewable energy used to support the supply chains under examination were taken into consideration using the Cumulative Energy Demand (CED) v2.0 (Vázquez-Rowe et al. 2014a; Tyedmers et al. 2005). SimaPro 8 was the software used for the computational implementation of the inventories (Goedkoop et al. 2016).

2.6. Statistical and sensitivity analysis

A statistical analysis was conducted in order to determine whether there were any significant differences between vessels or groups of vessels in terms of GHG emissions. However, a first limitation that was encountered when conducting the statistical analysis, despite having sampled approximately $78 \%$ of the total population of vessels, was the fact that there were not enough purse seiners sampled per port in order to conduct a meaningful statistical test. Moreover, the samples at hand did not correspond to a proper experimental design, since there was no randomization in the analyzed vessels or ports. Nevertheless, the available dataset has been used to provide some insight on the distribution of GHG emissions. For this, an ANOVA test was proposed (equivalent to a T- 

equivalent: the Kruskal-Wallis (KW) test. It should be noted that for the results of the ANOVA test to be conclusive, the samples must meet homogeneity of variances, using the Levene test, and normality, using the

\section{Shapiro-Wilk test.}

To complement the statistical analysis, a sensitivity analysis was also performed. Input parameters required to describe the supply chain of this production process can generate uncertainty due to their reliance on several assumptions. This is the case for LSW, engine weight or the lifespan of vessels and seine nets, among other parameters. Therefore, two of these parameters, vessel lifespan and seine net replacement, were evaluated in order to identify how their variation can affect environmental impact values. For vessels, the average lifespan was modelled for 20 and 40 years, being 30 years the reference value assumed in the main inventory. In the case of seine nets, the 5 year replacement period was complemented with a 2 and 10 year analysis.

\section{Results}

\subsection{Environmental performance of European anchovy fishery in Cantabria}

According to the results shown in Table 4, the main stage that was responsible for the greater part of the environmental impacts was the vessel use stage except for $\mathrm{MD}$ and human toxicity-cancer $\left(\mathrm{HT}_{\mathrm{c}}\right)$. More specifically, vessel use dominated the contribution to POF $\left(3.07 \cdot 10^{-2} \mathrm{~kg}\right.$ NMVOC eq), PMF $\left(1.09 \cdot 10^{-2} \mathrm{~kg} \mathrm{PM}_{10}\right.$

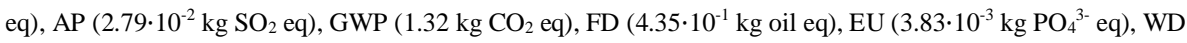
$\left(2.29 \cdot 10^{-3} \mathrm{~m}^{3}\right)$ and freshwater eco-toxicity FEP $\left(3.48 \cdot 10^{+1} \mathrm{CTUe}\right)$. On the other hand, vessel construction and maintenance were also important contributors MD $\left(3.51 \cdot 10^{-2}\right.$ and $3.98 \cdot 10^{-2} \mathrm{~kg}$ Fe eq, respectively). However, their contribution to the other categories was in all cases below $10 \%$. The other subsystem included in the analysis, vessel EoL, presented contributions in all cases below $1 \%$.

Impacts related to human toxicity and freshwater eco-toxicity can also be observed in Table 4. Vessel use accounted for $90 \%$ of the environmental impact for FEP, 56\% for human toxicity - non-cancer (HT $\mathrm{Hc}_{\mathrm{nc}}$ ) and $23 \%$ for $\mathrm{HT}_{\mathrm{c}}$. Vessel construction contributed to $\mathrm{HT}_{\mathrm{c}}$ in $57 \%$ and to $\mathrm{HT}_{\mathrm{nc}}$ in $13 \%$, while vessel maintenance contributed $20 \%$ to $\mathrm{HT}_{\mathrm{c}}$ and $31 \%$ to $\mathrm{HT}_{\mathrm{nc}}$. Environmental contribution for the different activities can be consulted in Figure S2 in Supporting Material (SM).

Table 4. Environmental impact of fishing $1 \mathrm{~kg}$ of European anchovy by purse seiners in Cantabria. GWP: global warming potential; AP: acidification potential; EU: eutrophication; WD: water depletion; -MD: metal depletion; FD: fossil depletion; POF: photochemical ozone formation; PMF: particulate matter formation; $\mathrm{HT}_{\mathrm{c}}$ : human toxicity, cancer; $\mathrm{HT}_{\mathrm{nc}}$ : human toxicity, non-cancer; FEP: freshwater ecotoxicity potential. 


\begin{tabular}{|c|c|c|c|c|c|}
\hline & Unit & $\begin{array}{c}\text { Vessel } \\
\text { Construction }\end{array}$ & $\begin{array}{c}\text { Vessel } \\
\text { Maintenance }\end{array}$ & $\begin{array}{l}\text { Vessel } \\
\text { Use }\end{array}$ & $\begin{array}{l}\text { Vessel } \\
\text { EoL }\end{array}$ \\
\hline GWP & $\mathrm{kg} \mathrm{CO}_{2} \mathrm{eq}$ & $4.93 \cdot 10^{-2}$ & $7.70 \cdot 10^{-2}$ & 1.32 & $5.52 \cdot 10^{-4}$ \\
\hline $\mathrm{AP}$ & $\mathrm{kg} \mathrm{SO}_{2} \mathrm{eq}$ & $3.02 \cdot 10^{-4}$ & $6.76 \cdot 10^{-4}$ & $2.79 \cdot 10^{-2}$ & $4.27 \cdot 10^{-6}$ \\
\hline EU & $\mathrm{kg} \mathrm{PO}_{4}^{-}$eq & $1.20 \cdot 10^{-4}$ & $2.76 \cdot 10^{-4}$ & $3.83 \cdot 10^{-3}$ & $4.86 \cdot 10^{-6}$ \\
\hline WD & $\mathrm{m}^{3}$ & $1.06 \cdot 10^{-3}$ & $1.93 \cdot 10^{-3}$ & $2.29 \cdot 10^{-3}$ & $6.81 \cdot 10^{-6}$ \\
\hline MD & kg Fe eq & $3.51 \cdot 10^{-2}$ & $3.98 \cdot 10^{-2}$ & $1.65 \cdot 10^{-2}$ & $4.87 \cdot 10^{-41}$ \\
\hline FD & kg oil eq & $1.47 \cdot 10^{-2}$ & $2.70 \cdot 10^{-2}$ & $4.35 \cdot 10^{-1}$ & $1.56 \cdot 10^{-4}$ \\
\hline POF & kg NMVOC & $1.84 \cdot 10^{-4}$ & $3.00 \cdot 10^{-4}$ & $3.07 \cdot 10^{-2}$ & $2.77 \cdot 10^{-6}$ \\
\hline PMF & kg $\mathrm{PM}_{10}$ eq & $1.25 \cdot 10^{-4}$ & $1.82 \cdot 10^{-4}$ & $1.09 \cdot 10^{-2}$ & $1.61 \cdot 10^{-6}$ \\
\hline $\mathrm{HT}_{\mathrm{c}}$ & $\mathrm{CTU}_{\mathrm{h}}$ & $2.43 \cdot 10^{-8}$ & $8.47 \cdot 10^{-9}$ & $9.67 \cdot 10^{-9}$ & $1.37 \cdot 10^{-10}$ \\
\hline $\mathrm{HT}_{\mathrm{nc}}$ & $\mathrm{CTU}_{\mathrm{h}}$ & $8.08 \cdot 10^{-8}$ & $1.92 \cdot 10^{-7}$ & $3.43 \cdot 10^{-7}$ & $2.36 \cdot 10^{-9}$ \\
\hline FEP & $\mathrm{CTU}_{\mathrm{e}}$ & 1.14 & 2.52 & $3.48 \cdot 10^{+1}$ & $5.89 \cdot 10^{-2}$ \\
\hline
\end{tabular}

As abovementioned, vessel use was the main contributor to most impact categories. However, when looking at the results in more detail (see Figure 5), it appears that most environmental burdens generated were due to fuel consumption for all impact categories, except for WD, MD, $\mathrm{HT}_{\mathrm{nc}}$ and FEP. For the rest of impact categories, its contribution was in all cases above $88 \%$. Seine net production and transport contributed to $7 \%$ in GWP, whereas ice production and antifouling and lubricant oil production and emissions showed contributions below $1 \%$. In WD and MD the production of the seine net had a relevant contribution, $40 \%$ and $20 \%$ respectively, while the production and use of diesel presented the highest contribution to FD, $89 \%$. The production and emissions of antifouling were relevant to $\mathrm{HT}_{\mathrm{nc}}$ (55\%) and FEP (83\%). Production of steel for the construction and maintenance of vessels and motors presented low contributions in all impact categories, except in terms of MD (31\%). The management of on board residues presented contributions below $10 \%$ in GWP, AP, EU, FD and $\mathrm{HT}_{\mathrm{nc}}$, whereas these were higher for WD (11\%), MD (13\%) and FEP (10\%). 

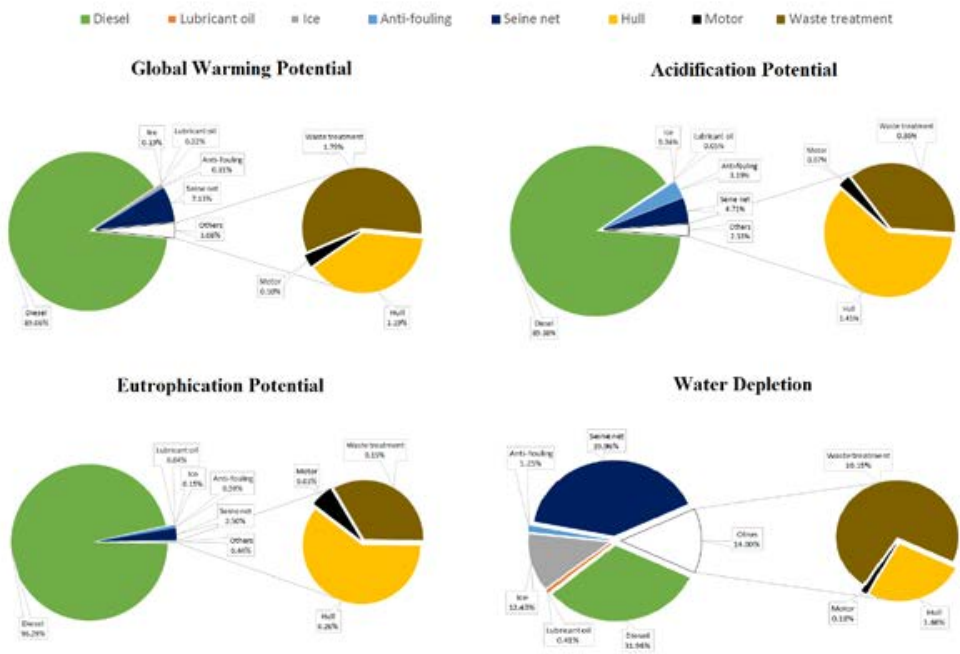

Water Depletion
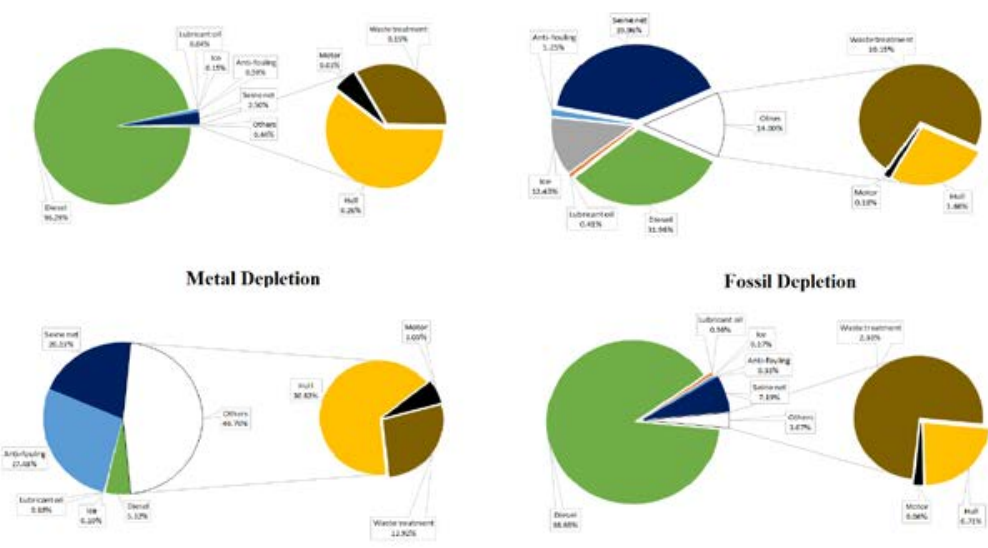

Human Toxicity, non-cancer
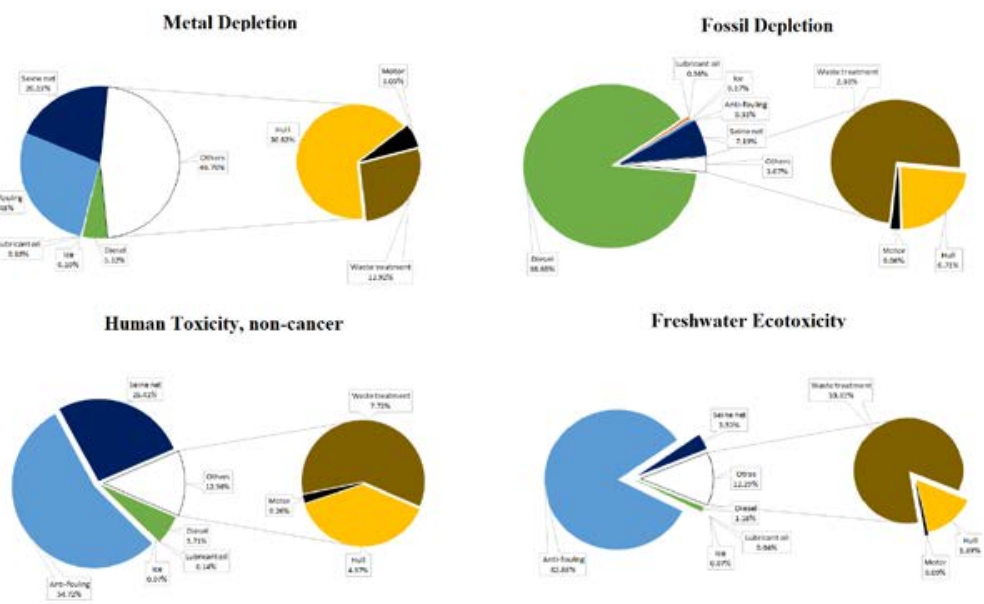

Figure 5. Environmental impact potential for the selected conventional impact categories for the average vessel per functional unit.

\section{2. $\quad$ Biotic Resource Use (BRU)}

The BRU value obtained for European anchovy was $13.99 \mathrm{~g} \mathrm{C} / \mathrm{kg}$ fish. This value is relatively low, in line with other small-pelagic species in the literature considering that European anchovy does not have a high TL (Parker and Tyedmers 2012). Figure 6 represents the PPR value of European anchovy as compared to the other anchovy species that are used in the canning industry in Cantabria. Data on TL were taken from FishBase (2016): 


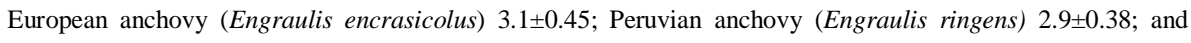

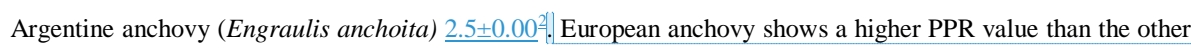
species, which, according to Coll et al. (2006), is based on its feeding patterns, more reliant on mesozooplankton, whereas Peruvian anchoveta, for instance, feeds mainly on phytoplankton. Nevertheless, it should be noted that European anchovy also presents a higher standard error in its PPR values.

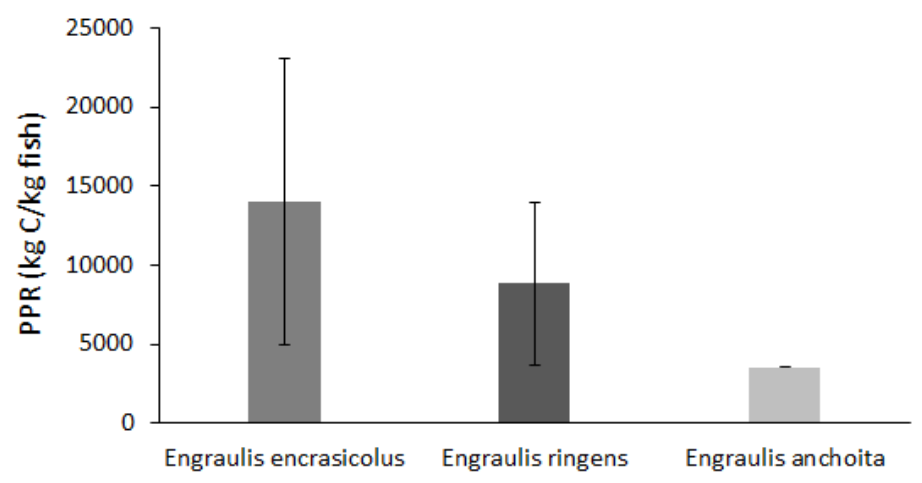

Figure 6. Primary Production Required (PPR) value of the European anchovy (Engraulis encrasicolus), Peruvian anchovy (Engraulis ringens) and Argentine anchovy (Engraulis anchoita). Data on trophic level (TL), including standard error, were taken from FishBase (2016): European anchovy (Engraulis encrasicolus) 3.1 \pm 0.45 ; Peruvian anchovy (Engraulis ringens) 2.9 \pm 0.38 ; Argentine anchovy (Engraulis anchoita) $2.5 \pm 0.00$

\subsection{Edible Protein energy return on investment (ep-EROI)}

The current study assessed the ep-EROI value for the anchovy captured by purse seining fishing vessels in Cantabria. The energy provided by anchovy was fixed at $2.18 \mathrm{MJ} / \mathrm{kg}$ anchovy (Peter Tyedmers, personal communication, September 2011) and the average value of CED was 22.5 MJ. The ep-EROI value was calculated for each vessel of the sample and the results indicated an average value of $12.2 \%$, with a minimum value of $3.3 \%$ (P5.2) and a maximum value of 30.3\% (P4.1).

\section{Discussion}

4.1. Identification of environmental hotspots

The environmental performance of the European anchovy fishery off the coast of Cantabria led to a first finding that the most important environmental impact associated with the operation of the fleet was linked to the

${ }^{2}$ A standard error of 0.00 was computed for Engraulis anhcoita, according to the data provided by FishBase (2016). This value is probably linked to the lack of multiple data points measuring the trophic level of this species. 
production, transportation and direct combustion of diesel. This result is not new in fisheries LCA studies, since most of the available literature highlights the direct use of fuels by vessels as the main environmental carrier in most impact categories (e.g., GWP, ODP, FD...). For instance, Fréon et al. (2014) previously presented similar results for the Peruvian anchoveta purse seining fleet, showing that the steel fleet presented the lowest fuel use intensity worldwide, although fuel production and use remained the main contributing operation. Hull construction and maintenance was the second item that contributed the most to environmental impacts. Moreover, other authors have also reported similar results for different small pelagic fish species: European pilchard (Almeida et al. 2014), Atlantic mackerel (Ramos et al. 2011), or horse mackerel (Vázquez-Rowe et al. 2010), but also for some large pelagic fish species, such as tuna or swordfish (Hospido and Tyedmers, 2005; Parker et al. 2015).

However, despite the fact that the consumption of diesel was the main hotspot of these analyzed studies, the consumption of diesel per kilogram of landed fish was very different (Table 5). Fréon et al. (2014) reported the lowest value, $15.6 \mathrm{~g}$ diesel/kg of landed fish for anchoveta for the period 2008-2011, while Hospido and Tyedmers (2005) reported a value very similar to the one reported in the current study, $364 \mathrm{~g}$ diesel $/ \mathrm{kg}$ fish landed. However, it should be noted that in the case of Hospido and Tyedmers, landings were performed by large industrial vessels operating in open sea, whereas in the current study purse seiners were smaller in size, landed less amount of catch and operated in the Spanish Exclusive Economic Zone (EEZ) along the continental shelf. In the other studies, Vázquez-Rowe et al. (2010) reported a value of 176 g diesel/kg fish landed, Almeida et al. (2014) 92 g diesel/kg fish landed and Ramos et al. (2011) $27 \mathrm{~g}$ diesel/kg fish landed. Pelagic species targeted by trawlers presented a much stronger dominance of energy use. Therefore, it appears as if the European anchovy fleet is located in the upper range of pelagic species in terms of fuel use intensity (FUI), but still substantially lower than trawling fleets targeting pelagics. The data collected for the current study only allowed analyzing one year of operation, making it difficult to hypothesize the causes behind this relatively high FUI value. However, previous studies have suggested that relevant fuel efficiency improvements can be attained following stock rebuilding (Ziegler and Hornborg 2014). Therefore, considering the volatility of the European anchovy fishing stock in the Bay of Biscay in the past decade, future research should delve into the role of recruitment, stock size and size of individuals to determine whether the apparent recovery of the fishery is gradually translating into fuel savings.

Table 5. Diesel consumption of other pelagic species fisheries reported in the literature. 


\begin{tabular}{|c|c|c|c|c|}
\hline Species & Unit & Fishing gear & Value & Reference \\
\hline European anchovy & g diesel/FU & Purse seining & 340.0 & Current study \\
\hline Anchoveta & g diesel/FU & Purse seining & 15.6 & Fréon et al. 2014 \\
\hline Sardine & g diesel/FU & Purse seining & 91.5 & Almeida et al. 2014 \\
\hline Atlantic mackerel & g diesel/FU & Purse seining & 26.9 & Ramos et al. 2011 \\
\hline Horse mackerel & g diesel/FU & Purse seining & 176.0 & Vázquez-Rowe et al. 2010 \\
\hline Tuna & g diesel/FU & Purse seining & 364.3 & Hospido and Tyedmers 2005 \\
\hline Tuna & g diesel/FU & Purse seining & 306.4 & Parker et al. 2015b \\
\hline Atlantic mackerel & g diesel/FU & Trawling & 496.0 & Vázquez-Rowe et al. 2010 \\
\hline Common octopus & g diesel/FU & Trawling & 1287.0 & Vázquez-Rowe et al. 2012b \\
\hline Pelagic species & g diesel/FU & Trawling & 354.0 & Jafarzadeh et al. 2016 \\
\hline $\begin{array}{l}\text { Small pelagic species } \\
\text { (Europe) }\end{array}$ & g diesel/FU & Trawling & 149.0 & Parker and Tyedmers 2015 \\
\hline Pelagic species & g diesel/FU & Coastal seining & 56.0 & Jafarzadeh et al. 2016 \\
\hline
\end{tabular}

An important limitation of this study is the fact that most operational activities, including the use of diesel, were reported on an annual basis. Therefore, it was not possible to disaggregate fuel use per landed species, despite the fact that the purse seining fleet from Cantabria has a fairly delimited season for each one of the main species it lands. Based on this assumption, it could be hypothesized that different operations and skipper behavior when targeting different species throughout the year could translate into an important source of uncertainty in this study.

Anti-fouling emissions to the ocean generated reduced burdens for most impact categories, but its contribution to freshwater toxicity is relevant due to the emissions of copper and zinc. However, it should be noted that corrosion from vessels is an unexplored impact in seafood LCA studies that may cause certain environmental impacts, especially in terms of eco-toxicity.

The management of non-hazardous wastes had also an important contribution to human and freshwater eco-toxicity due to the emissions produced in the incineration process, as well as to water and metal depletion. Regarding water depletion, however, it should be noted that the impact category used considers a raw calculation of the amount of water used in the production system, without taking into account geographical/regional availability or scarcity (Goedkoop et al. 2009). In fact, water footprint has been a repeatedly overlooked impact category in fisheries LCA through the years. Results shown in this study demonstrate that total water use $(5.29 \cdot 10$ - 
3 m3/FU) represents a relatively low value as compared to most agricultural products (Vázquez-Rowe et al. 2016; Lovarelli et al. 2016). However, as shown in Figure 6, WD is distributed evenly throughout several subsystems (e.g., seine net production, diesel, ice, waste treatment, etc.). Therefore, considering the variety of water sources included in the inventory, the use of more refined water-related characterization factors, as those recently released in the AWARE method, may provide interesting insights linked to the water footprint of seafood products (Boulay et al., 2015; WULCA, 2016).

Vessel and seine net EoL did not represent relevant contributions to the product systems' environmental burdens. This fact leads to the apparent conclusion that EoL may not be key subsystem compared with others. Nonetheless, it should be studied in depth, since the study of the EoL of vessels constitutes a major gap in LCA. Only some authors have reported some results. For instance, Gilbert et al. (2016) compared two ships under an LCA approach analyzing two EoL scenarios: (i) reusing the hull as a whole and (ii) decommissioning the hull. Choi (2016) determined the economic feasibility and environmental impacts of three examples of EoL: standard ship recycling, substandard ship recycling and reefing. On the other hand, Ko and Gantner (2016) performed an environmental and economic analysis to calculate the imbalance in the distribution of the added value and the harm to the environment over the lifetime of a ship employing the dismantling as EoL.

It is important to highlight that in this study electronic components (i.e., radars, sonars, computers, screens, etc.) of vessels were not considered. However, these electronic products contain many materials requiring special EoL handling, such as lead, mercury, arsenic, chromium, cadmium and plastics capable of releasing, if not managed adequately, compounds such as dioxins or furans (Sthiannopkao and Wong 2013). The European Union has been adopting a number of community level regulations related to commonly known as e-waste (European Commission 2012; European Commission 2011). These measurements include dismantling of parts and recyclability of materials, proper collection systems that support separate collection of e-waste (also referred to as "waste of electrical and electronic equipment" - WEEE) to reduce disposal in common municipal waste streams, and best practices for treatment, recovery and recycling of e-waste (Kahhat et al. 2008). Some authors have studied the environmental impact of e-waste treatment via LCA. Song et al. (2012) demonstrated that the recovery of metals, glass and plastic from e-waste can generate environmental benefits. Niu et al. (2012) compared three scenarios (incineration, manually dismantling and mechanical dismantling) using LCA. Their results showed that incineration has the greatest impact, followed by mechanical dismantling. Moreover, incineration has a poor reputation because of its emissions of greenhouse gases, acid gases, and dioxins and furans (Margallo et al. 2014). For the BRU impact category it can be observed that the Cantabrian purse seining fleet shows relatively 
low BRU values (Table 6), due to the fact that European anchovy is a species that is situated in a lower TL than most fish species landed in Spain (Vázquez-Rowe et al. 2012a). Interestingly, many fisheries worldwide that capture species similar to European anchovy send their landing to reduction to produce fishmeal or fish oil (Fréon et al. 2014c). In fact, clear examples of this are the Peruvian anchoveta and US menhaden fisheries, sending over 99\% of their catch to reduction (Cashion et al. 2016). However, the European anchovy captured by Cantabrian purse seining vessels is used exclusively to process products for direct human consumption - DHC (Laso et al. 2016a and 2016b). Other low TL species are destined to DHC in Spain, such as European pilchard (VázquezRowe et al., 2014), tend to be used elsewhere for reduction. There use as DHC demonstrates that there can be a potential market as DHC for these species, rather than sending them to more complex, and usually more intensive in terms of energy and biotic impact, food supply chains (Cashion et al. 2016).

Table 6. Biotic Resource Use (BRU) values for other fish species collected in the literature.

\begin{tabular}{lccc}
\hline Specie & Unit & BRU & Reference \\
\hline European anchovy & $\mathrm{kg} \mathrm{C} / \mathrm{kg}$ fish & 13,988 & Current study \\
Peruvian anchovy & $\mathrm{kg} \mathrm{C} / \mathrm{kg}$ fish & 5,786 & Avadí and Fréon 2015 \\
Gulf menhaden & $\mathrm{kg} \mathrm{C} / \mathrm{kg}$ fish & 1,721 & Parker and Tyedmers 2012 \\
Antarctic krill & $\mathrm{kg} \mathrm{C} / \mathrm{kg}$ fish & 1,761 & Parker and Tyedmers 2012 \\
Atlantic herring & $\mathrm{kg} \mathrm{C/kg} \mathrm{fish}$ & 18,869 & Parker and Tyedmers 2012 \\
Blue whiting & $\mathrm{kg} \mathrm{C} / \mathrm{kg}$ fish & 133,699 & Parker and Tyedmers 2012 \\
\hline
\end{tabular}

The ep-EROI results provide valuable information regarding energy requirements of the Cantabrian purse seining fishing fleet. As observed in Table 7 , the value obtained in this study, $12.2 \%$, is similar to those obtained in other purse seining fisheries (Vázquez-Rowe et al. 2014a; Ramos et al. 2011), although substantially lower than some collected in the literature (Tyedmers 2001). Therefore, despite the values for this fishery being in the lower range for pelagic species landed by purse seiners, its results are still considerably better as compared to trawlers.

Table 7. Edible protein energy return on investment (ep-EROI) values for other pelagic species.

\begin{tabular}{lccc}
\hline Species & Fishing gear & ep-EROI (\%) & Reference \\
\hline European anchovy & Purse seining & 12.2 & Current study \\
Atlantic mackerel & Purse seining & 68.6 & Tyedmers 2001
\end{tabular}




\begin{tabular}{lccc}
$\begin{array}{l}\text { Atlantic mackerel } \\
\text { Tuna }\end{array}$ & $\begin{array}{l}\text { Purse seining } \\
\text { Purse seining }\end{array}$ & 17.8 & Vázquez-Rowe et al. 2014a \\
Horse mackerel & Purse seining & 14.9 & Ramos et al. 2011 \\
European pilchard & Purse seining & 18.3 & Vázquez-Rowe et al. 2014a \\
European hake & Trawling & 5.6 & Vázquez-Rowe et al. 2014a \\
Horse mackerel & Trawling & 6.1 & Vázquez-Rowe et al. 2014a \\
Atlantic mackerel & Trawling & 7.3 & Vázquez-Rowe et al. 2014a \\
\hline
\end{tabular}

Other fishery-specific impact categories, such as the seafloor impact potential (SIP) proposed by Nilsson and Ziegler (2007), were not applied to this fishery because it was assumed that purse seining was a fishing gear that caused negligible direct damage on the seafloor according to the SIP index due to the lack of contact with the seabed (Hornborg et al. 2012; Langlois et al. 2015; Ziegler and Valentinsson 2008). However, lost nets can potentially create ghost fishing, that is to say, the mortality of fish and other species that takes place after all control of fish gear is lost by a fisher (Brown and Macfadyen 2007). Similarly, discards in this fishery were considered minimal and were not computed (Pelletier et al. 2007; Vázquez-Rowe et al. 2011b).

\subsection{Global Warming Potential of the whole life cycle of canned anchovy}

As abovementioned, most European anchovy landed in Cantabria is sent to canning factories. The most common final product destined to DHC is a $150 \mathrm{~g}$ aluminum can that contains $30 \mathrm{~g}$ of processed anchovy and 20 g of olive oil. It should be noted that during anchovy processing approximately $60 \%$ of the wound weight of the individuals is lost, including heads, spines and broken anchovies, which are valorized into fishmeal and anchovy paste (Laso et al, 2016a). Figure 7 presents the relative GHG emissions emitted in each phase of the life cycle of one $50 \mathrm{~g}$ can of European anchovy in olive oil. The GWP related to the processing, wholesale and retail, use and end of life of canned anchovies was taken from Laso et al. (2016b). For the post-processing stages, it was considered that the canned anchovies were transported from the canning plant to a logistic hub, and then to a supermarket, and consumed as ready-to-eat products that do not required any cooking. Finally, in the EoL the packaging materials were disposed of in a landfill (Laso et al. 2016b).

Results show that the anchovy fishery would account for $44 \%$ of the total GHG emissions, whereas the processing stage would represent $45 \%$ of total impacts. A previous study in the literature, developed for canned sardines in Galicia, established that the processing stage to produce canned sardines represented approximately 77\% of total GWP while the sardine fishery accounted 5\% of the total GHG emissions (Vázquez-Rowe et al. 

or sterilization (Vázquez-Rowe et al. 2014b). Therefore, the energy demand of the canned sardines was higher.

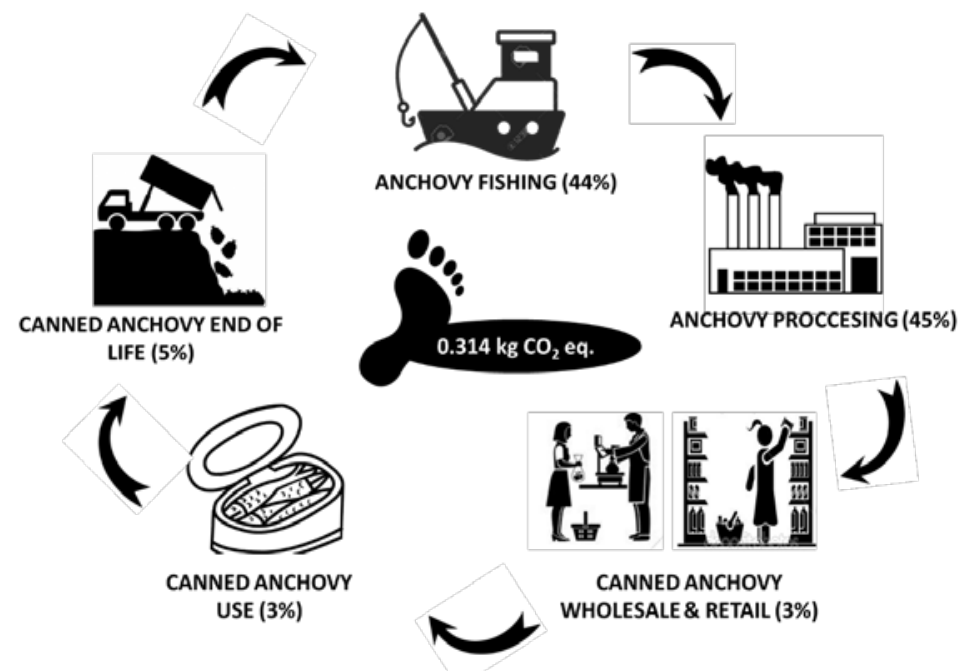

Figure 7. Global Warming Potential of the life cycle of one can of canned anchovies in olive oil.

\subsection{Trends between ports and vessels}

When the GWP is analyzed per port, as shown in Figure 8, the values range from $0.82 \mathrm{~kg} \mathrm{CO}_{2}$ eq (P4) to $1.91 \mathrm{~kg} \mathrm{CO}_{2}$ eq (P3). However, it should be noted that ports P6 and P7 only reported one vessel each; therefore, the samples for these two ports were not representative. It was expected that ports that were situated in the same zone presented similar values of GWP. Interestingly, this fact did not occur. P3 and P4 were situated in West Cantabria and they had very different GWP values: $1.91 \mathrm{~kg} \mathrm{CO}_{2} \mathrm{eq}$ and $0.82 \mathrm{~kg} \mathrm{CO} \mathrm{Cq}_{2}$, respectively. Similarly, P1, P2 and P5, which are located in Cantabria, presented a wide range of average GHG emissions per FU: 1.21 $\mathrm{kg} \mathrm{CO} 2 \mathrm{eq}, 1.48 \mathrm{~kg} \mathrm{CO}_{2} \mathrm{eq}$ and $1.86 \mathrm{~kg} \mathrm{CO}_{2} \mathrm{eq}$, respectively. Therefore, no trend was observed between ports in terms of vicinity or based on their proximity to the fishing ground.

Figure 9 shows the GHG emissions for each of the 32 vessels studied. In this case, the environmental impact ranged from $0.55 \mathrm{~kg}$ of $\mathrm{CO}_{2} \mathrm{eq}(\mathrm{P} 4.1)$ to $4.42 \mathrm{~kg}$ of $\mathrm{CO}_{2} \mathrm{eq}(\mathrm{P} 5.2)$. It was observed that vessels belonging to the same port presented similar values of GWP, i.e. P1, P3 and P4, although there were some vessels that had substantially higher GWP values than the average of their ports (e.g., P2.2, P5.2 or P5.6).

These results suggest the existence of certain differences between vessels in terms of their operational 
activities. In fact, this variability could be caused by a series of differences in vessel characteristics, such as size, age, engine power or tonnage, geographical distribution of the vessel, including landing and base port, technological improvements, and a set of operational issues relating to the use of resources, such as gear, fuel or ice use (Basurko et al. 2013; Vázquez-Rowe and Tyedmers 2013). In this study, the sample studied was very homogeneous, the age of the vessels ranged from 11 to 20 years, the size of the vessels and the engine power were very similar and the materials used in vessel construction were practically the same. Moreover, the distance from the ports to the fishing zone was between 100 and 150 miles in all cases. Therefore, the technical differences between the units assessed appeared to be relatively low. Data gaps and misreporting were also considered to be minimal, since data were supplied directly by the skippers. Finally, illegal, unreported and unregulated (IUU) fishing were also considered to be low, given the strict controls from authorities and certification agencies (González-García et al. 2015). Consequently, these results may be linked to the skill of the skipper and other members of the crew to sense where the catch will be available. This fact, usually named as the "skipper effect", has generated high controversy and interest in the literature (Russell and Alexander 1996; Ruttan and Tyedmers 2007). Several studies reported the fact that the "skipper effect" tends to be more noticeable in seining fleets than in other industrial fleets, such as trawlers or long liners (Gaertner et al. 1999). For instance, strong correlations between the "skipper effect" and vessel efficiency were identified in the US menhaden purse seining fleets (Ruttan and Tyedmers 2007; Vázquez-Rowe and Tyedmers 2013).

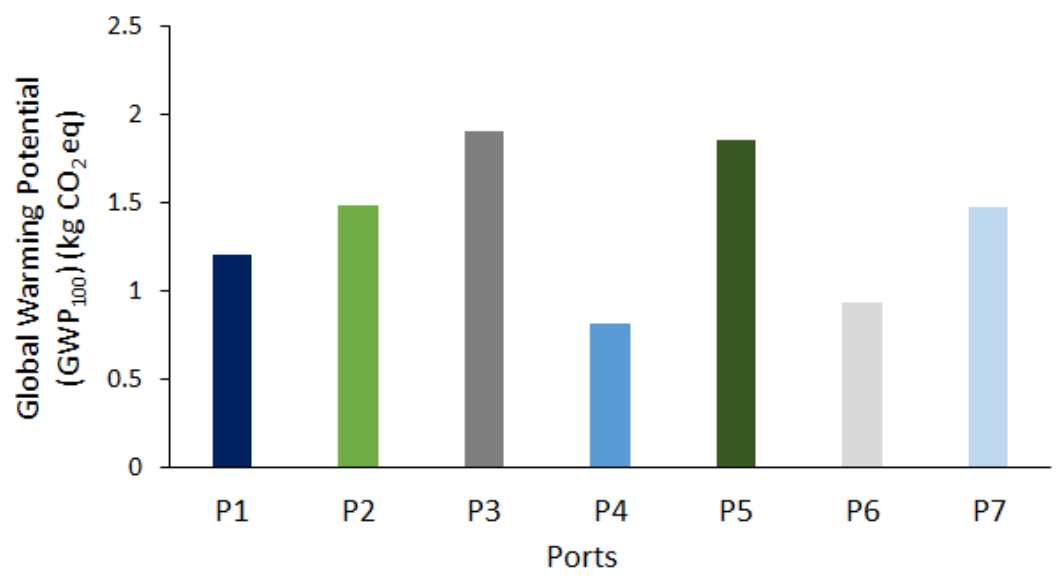

Figure 8. Global warming potential (GWP) average value of each Cantabrian port. P1: Colindres; P2: Santoña; P3: San Vicente de la Barquera; P4: Comillas; P5: Laredo; P6: Santander; P7: Castro Urdiales. 


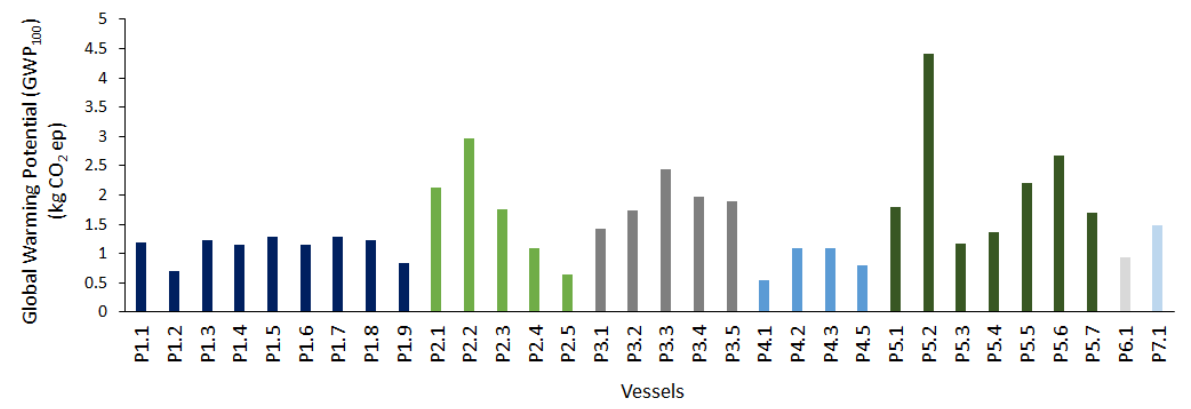

Figure 9. Global warming potential (GWP) of the 32 vessels studied. The letter $P$ followed by the first digit represents the port of origin for each vessel, P1: Colindres; P2: Santoña; P3: San Vicente de la Barquera; P4: Comillas; P5: Laredo; P6: Santander; P7: Castro Urdiales. The second digit represents the number of each vessel within its port of origin.

The results obtained from the statistical analysis showed that when plotting the entire data sample on a histogram (see Figure S1 in the SM) a clear asymmetry is identified in the distribution of the results. This is also highlighted by the inclusion of a kernel density estimator, also shown in Figure S1. Therefore, the sample of 32 vessels was divided into two groups based on the average GHG emission results per port, as a proxy of the fuel used for propulsion. In other words, each vessel was assigned to a high-GWP port group or a low-GWP port group on the basis of the GHG emissions port average. In other words, if a certain vessel belongs, for instance, to a low fuel consumption/production port, it does not mean that its own GWP value is "low". Hence, the statistical analysis conducted allows determining the homogeneity of vessels in terms of GWP with respect to the port classification. For that purpose, and bearing in mind that the considerations described in section 2.6 must be taken into account when interpreting the results, two procedures were run: an ANOVA test and a Kruskal-Wallis test. The two groups were generated using a cut-off criteria at $1.46 \mathrm{~kg} \mathrm{CO}_{2}$ eq, obtaining balanced samples (i.e., 15 units for $<1.46 \mathrm{~kg}$ $\mathrm{CO}_{2}$ eq and 17 units for $>1.46 \mathrm{~kg} \mathrm{CO}$ eq; see Figure S2 in the SM). Another cut-off point had been set previously at $1.50 \mathrm{~kg} \mathrm{CO}_{2}$ eq, but it was finally discarded due to a higher number of atypical values in the sample (see Figure S3 in the SM). Hence, the hypotheses were redefined in order to determine whether: i) the average GWP values were the same for both groups; and ii) if distribution of values in both groups was the same.

The first hypothesis was tested using an ANOVA procedure, whereas for the second problem the U Mann-Whitney test was run. Nevertheless, considering that there are only two groups in the analysis, the use of an ANOVA is equivalent to a T-test. For the ANOVA procedure, normality and homogeneity of variances in the 
groups must be assessed in advance. For that purpose, Shapiro-Wilk and Levene tests were applied, respectively.

Results, presented in Table S2 in the SM, demonstrate that there is no evidence to reject the hypothesis of normality and homogeneity of variances (with p-values above the usual significance levels of $5 \%$ or $1 \%$ ). Therefore, the samples meet the prerequisites to conduct an ANOVA test, as long as a 1\% significance level is set for the homogeneity of variances. The output of the ANOVA provided a p-value below the usual significance levels, indicating that the means in the two groups are different. Similarly, the U Mann-Whitney test shows a pvalue under the significance level, which also indicates that there is a significant difference between the distributions of the values in both samples. That is, not only the mean GWP values are different, but also their distributions (see Figure S2 in the SM).

It should be noted that results suggest a significant difference between the two groups of vessels, but not of each port individually given the low sample size per port. The sample size and the detail of data for the vessels were a limitation to conduct more detailed statistical analyses on the purse seining fleet. However, considering that the similarity of the sample in terms of vessel size, captured species or fishing areas is remarkable, we hypothesize that the differences could be due to the type of engine that is been used, or due to the skill of the skipper/crew. In fact, the "skipper-effect”, although not directly analyzed in this study, has been pointed out as a critical issue when considering differences in behavior among vessels (Vázquez-Rowe and Tyedmers 2013; Ruttan and Tyedmers 2007; González-García et al. 2015).

Regarding the sensitivity analysis, Figure 10 displays the GWP, WD, MD and $\mathrm{HT}_{\mathrm{c}}$ per functional unit when the estimated lifespan of the vessels and the seine nets were varied. In terms of GWP and WD, the vessels lifespan showed very low variation, whereas the seine nets lifespan presented a variation of WD from $7.74 \cdot 10^{-3}$ $\mathrm{m}^{3}$ (2 years) to $4.47 \cdot 10^{-3} \mathrm{~m}^{3}$ (10 years). In terms of $\mathrm{MD}$ and $\mathrm{HT}_{\mathrm{c}}$, the variation of both vessels and seine nets lifespan resulted in a change in the environmental impact. In particular, MD and $\mathrm{HT}_{\mathrm{c}}$ decreased 22\% and 33\%, respectively, when vessels lifespan varied from 20 to 40 years. On the other hand, when seine nets lifespan ranged from 2 to 10 years, MD and $\mathrm{HT}_{\mathrm{c}}$ decreased $21 \%$ and $17 \%$, respectively. 

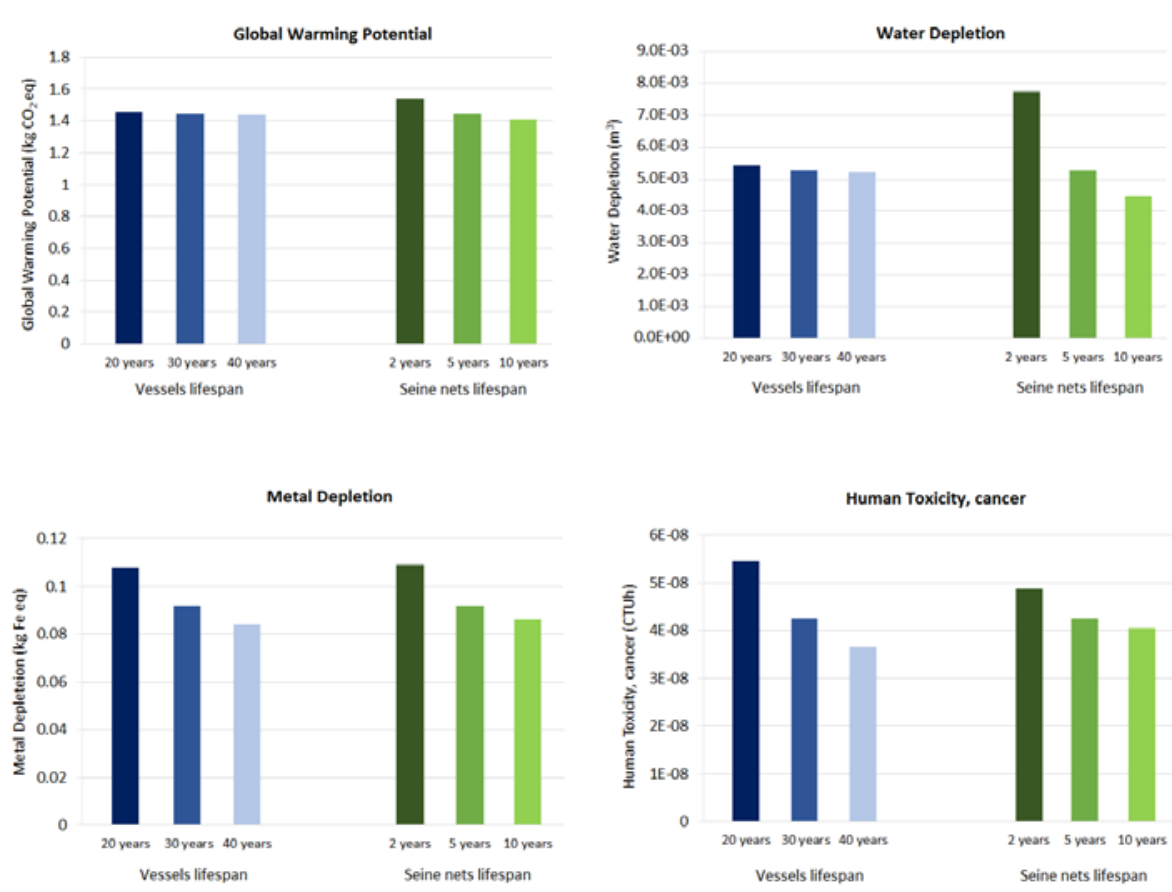

Figure 10. Graphical representation of the sensitivity analysis. Variation in Global Warming Potential, Water Depletion, Metal Depletion and Human Toxicity - cancer per functional unit based on changes in the estimated lifetime of the vessels and seine nets.

\section{Conclusion}

The European anchovy purse seining fleet in northern Spain represents an emblematic and high valueadded fishery. Its closure due to overexploitation at the beginning of the century is probably the cause of the lack of a previous LCA study, since every other major pelagic species caught throughout the Spanish northern coast has already been reported in the seafood LCA literature. Therefore, this study aimed at filling that gap. For this, data on 32 vessels, representing roughly $75 \%$ of this fleet, were obtained to elaborate an exhaustive inventory, which collected the main inputs and outputs of the construction, use, maintenance and EoL of each vessel.

The LCA results were driven by diesel production, transportation and use in most conventional impact categories. In fact, FUI values appear to be in the upper range for small pelagic species when compared to previous fuel intensity studies elsewhere, despite the fact that distances to the fishing grounds are relatively short. The use of anti-fouling paints was identified as the main hotspot in toxicity potential, due to the emissions of zinc and 
copper, whereas the remaining activities, as well as the construction and EoL of the vessel presented lower relative contributions. However, we argue that for the latter the repeated exclusion of certain capital goods, such as electronic equipment, or a more detailed inventory in terms of vessel construction may hide certain environmental impacts, especially in terms of waste generation and treatment.

A statistical analysis was also carried out to identify the significance of the differing values obtained between ports and vessels. However, given the low amount of vessels in the fleet, analysis at a port level was discarded. When several ports were aggregated based on the average GHG emissions of their vessels per FU, results suggest that there is a significant difference between the ports. Unfortunately, available data were not enough to identify the causes of this difference, although we hypothesize that mechanical or temporal characteristics of the motors, or the so called "skipper effect” could well explain these trends.

Future research in the frame of the same project will include the combination of LCA with Data Envelopment Analysis, a linear programing management tool, with the aim of identifying the best performing fishing vessels in the fleet in terms of environmental efficiency, as well as the sources of inefficiency among the inventoried sample. In addition, future progress will be needed in the stock management of the European anchovy fishery in order to attain more meaningful assessments in terms of biotic impacts.

\section{Acknowledgements}

The authors thank the Ministry of Economy and Competitiveness of the Spanish Government for their financial support via the project GeSAC-Conserva: Sustainable Management of the Cantabrian Anchovies (CTM201343539-R) and to Pedro Villanueva-Rey for valuable scientific exchange. Jara Laso thanks the Ministry of Economy and Competitiveness of Spanish Government for their financial support via the research fellowship BES-2014-069368 and to Ministry of Rural Environment, Fisheries and Food of Cantabria for the data support. Dr. Ian Vázquez-Rowe thanks the Peruvian LCA Network for operational support. Reviewers are also thanked for the valuable and detailed suggestions. The work of Dr. Rosa M. Crujeiras has been funded by MTM201676969P (AEI/FEDER, UE).

\section{References}

Almeida C, Vaz S, Cabral H, Ziegler F (2014). Environmental assessment of sardine (Sardina pilchardus) purse seine fishery in Portugal with LCA methodology including biological impact categories. Int J Life Cycle Assess 19: 297-306.

Avadí A, Fréon P (2015). A set of sustainability performance indicators for seafood: Direct human consumption products from Peruvian anchoveta fisheries and freshwater aquaculture. Ecol Indic 48: 518-532. 
Avadí A, Fréon P, Quispe I (2014a). Environmental assessment of Peruvian anchoveta food products: Is less refined better? Int J Life Cycle Assess 19 (6): 1276-1293.

Avadí A, Vázquez-Rowe I, Fréon P (2014b). Eco-efficiency assessment of the Peruvian anchoveta steel and wooden fleets using the LCA+DEA framework. J Clean Prod 70: 118-131.

Ayer N, Tyedmers P, Pelletier N, Sonesson U, Scholz A (2007). Co-Product Allocation in Life Cycle Assessment of Seafood Production Systems: Review of Problems and Strategies. Int J of Life Cycle Assess 12(7): 480-487.

Bala A, Raugei M, Fullana i Palmer P (2014). Introducing a new method for calculating the environmental credits of end-of-life material recovery in attributional LCA. Int J Life Cycle Assess 20(5): 645-654.

Basurko O.C, Gabiña G, Uriondo Z (2013) Energy performance of fishing vessels and potential savings. $J$ Clean Prod 54: 30-40.

Boulay A. M, Bare J, De Camillis C, Döll P, Gassert F, Gerten D, Humbert S, Inaba A, Itsubo N, Lemoine Y, Margni M, Motoshita M, Núñez M, Pastor A.V, Ridoutt B, Schencker U, Shirakawa N, Vionnet S, Worbe S, Yoshikawa S, Pfister S (2015) Consensus building on the development of a stress-based indicator for LCA-based impact assessment of water consumption: outcome of the expert workshops. Int J Life Cycle Assess 20(5): 577583.

Brown J, Macfadyen G (2007). Ghost fishing in European waters: impacts and management responses. Mar Policy 31(4): 488-504.

Cashion T, Tyedmers P, Parker R (2016) What we feed matters: differences in life cycle greenhouse gas emissions and primary productivity requirements to sustain provision of fish meals and oils. LCA of Foods 2016, Ireland: Dublin.

Choi J, Kelley D, Murphy S, Thangamani D (2016). Economic and environmental perspectives of end-of-life ship management. Resour Conserv Recy 107: 82-91.

Ecoembes. 2015. Available at https://www.ecoembes.com/es/ciudadanos/envases-y-proceso-reciclaje/reciclajeen-datos/barometro.

Ecoinvent. 2016. Available at http://www.ecoinvent.org/.

Emanuelsson A, Ziegler F, Pihl L, Sköld M, Sonesson U (2014). Accounting for overfishing in life cycle assessment: new impact categories for biotic resource use. Int J Life Cycle Assess 19(5): 1156-1168.

EMEP-Corinair, 2006. Emissions Inventory Guidebook, Available at http://www.eea.europa.eu/publications/EMEPCORINAIR4.

EMEP/EEA (2013). Air Pollutant Emission Inventory Guidebook. Available at http://www.eea.europa.eu//publications/emep-eea-guidebook-2013.

Eurofish (2012). Overview of the world's anchovy sector and trade possibilities for Georgian anchovy products. Eurofish International Organization

European Commission (2012). Directive 2012/19/EU of the European Parliament and of the Council of 4 July 
European Commission (2011). Directive 2011/65/EU of the European Parliament and of the Council of 8 June 2011 on the restriction of the use of certain hazardous substances in electrical and electronic equipment. Official Journal of the European Union, L 174/88.

FishBase (2016). Available at http://www.fishbase.org/search.php.

Fréon P, Cury P, Shannon L, Roy C (2005). Sustainable exploitation of small pelagic fish stocks challenged by environmental and ecosystem changes: a review. B Mar Sci 76(2): 385-462.

Fréon P, Avadí A, Soto W.M, Negrón R (2014a). Environmentally extended comparison table of large- versus small- and medium-scale fisheries: The case of the Peruvian anchoveta fleet. Can J Fish Aquat Sci 71 (10): 14591474 .

Fréon P, Avadí A, Vinatea-Chavez R.A, Iriarte F (2014b). Life cycle assessment of the Peruvian industrial anchoveta fleet: boundary setting in life cycle inventory analyses of complex and plural means of production. Int J Life Cycle Assess 19: 1068-1086.

Fréon P, Sueiro J.C, Iriarte F, Miro Evar O.F, Landa Y, Mittaine J.F, Bouchon M (2014c). Harvesting for food versus feed: A review of Peruvian fisheries in a global context. Rev Fish Biol Fisher 24 (1): 381-398.

Frischknecht R, Jungbluth N, Althaus H.J, Doka G, Heck T, Hellweg S, Hischier R, Nemecek T, Rebitzer G, Spielmann M, Wernet G (2007). Overview and Methodology. Ecoinvent Report No, 1, Swiss Centr for Life Cycle Inventories, Dübendorf.

García-Cobo P.L (1998). La importancia del sector conservero en la economía de Santoña y Cantabria. Asociación de Fabricantes de Conservas de Pescado de Cantabria, 95-99.

Gaertner D, Pagavino M, Marcano J (1999). Influence of fisheries'behavior on the catchability of surface tuna schools in the Venezuelan purse-seiner fishery in the Caribbean Sea. Can J Fish Aquat Sci, 56: 394-406.

Gilbert P, Wilson P, Walsh C, Hodgson P. (2016). The role of material efficiency to reduce $\mathrm{CO}_{2}$ emissions during ship manufacture: a life cycle approach. Mar Policy, 75: 227-237.

Goedkoop M, Heijungs R, Huijbregts M, Schryver A, Struijis J, Van Zelm R (2009). ReCIPE 2008. A life cycle impact assessment method which comprises harmonized category indicators at the midpoint and the endpoint.

Goedkoop M, Oele M, Leijting J, Ponsioen T, Meijer E (2016). Introduction to LCA with SimaPro 8. PRé Consultants, The Netherlands.

González-García S, Villanueva-Rey P, Belo S, Vázquez-Rowe I, Moreira M.T, Feijoo G, Arroja L (2015). Crossvessel eco-efficiency analysis. A case study for purse seining fishing from North Portugal targeting European pilchard. Int J Life Cycle Assess 20: 1019-1032.

Guascor (2016). Guascor Marine Diesel Engines and Systems. Available at http://www.dresserrand.com/products-solutions/guascor-gas-diesel-engines/.

Guinée J.B, Gorrée M, Heijungs R, Huppes G, Kleijn R, de Koning A, van Oers L, Wegener A, Suh S, Udo de Haes H.A (2001). Life Cycle Assessment. An Operational Guide to the ISO Standards. Centre of Environmental 
Hauschild M.Z, Goedkoop M, Guinée J, Heijungs R, Huijbregts M, Jolliet O, Margni M, De Schryver A, Humbert S, Laurent A, Sala S, Pant R (2013). Identifying best existing practice for characterization modelling in life cycle impact assessment. Int J Life Cycle Assess 18(3): 683-697.

Hornborg S, Nilsson P, Valentisson D, Ziegler F (2012). Integrated environmental assessment of fisheries management: Swedish Nephrops trawl fisheries evaluated using a life cycle approach. Mar Policy 36(6): 11931201.

Hospido A, Tyedmers P (2005). Life cycle environmental impacts of Spanish tuna fisheries. Fish Res 76: 174186.

ICES (2014). ICES advice December 2014 for European anchovy. Available at http://www.ices.dk/sites/pub/Publication\%20Reports/Advice/2014/Special\%20Requests/EU_Bay_of_Biscay an chovy TAC.pdf

ILCD (2011). Recommendations for Life Cycle Assessment in the European context- based on existing environmental impact assessment models and factors. Joint Research Centre. ISBN: 978-92-79-17451-3.

IPCC (2006). Guidelines for National Greenhouse Gas Inventories. Available at http://www.ipccnggip.iges.or.jp/public/2006gl/spanish/.

IPCC (2013). Climate Change 2013. The Physical Science Basis. Working Group I contribution to the $5^{\text {th }}$ Assessment Report of the IPCC. Intergovernamental Panel on Climate Change. Available at: http://www.climatechange2013.org (Last accessed: June 30 ${ }^{\text {th }}$ 2016).

ISO (2006a). ISO 14040: Environmental Management - Life Cycle Assessment - Principles and Framework. International Standards Organization. Geneva. Switzerland.

ISO (2006b). ISO 14044: Environmental Management - Life Cycle Assessment - Requirements and Management. International Standards Organization. Geneva. Switzerland.

Jafarzadeh S, Ellingsen H, Aanond-Aanondsen S (2016). Energy efficiency of Norwegian fisheries from 2003 to 2012. J Clean Prod 112: 3616-3630.

Kahhat R, Kim J, Xu M, Allenby B, Williams E, Zhang P (2008). Exploring e-waste management systems in the United States. Resour Conserv Recy 52: 955-964.

Ko N, Gantner J (2016). Local added value and environmental impacts of ship scrapping in the context of a ship's cycle. Ocean Eng 122: 317-321.

Langlois J, Fréon P, Delgenes J.P, Steyer J.P, Hélias A (2014). New methods for impact assessment of bioticresource depletion in life cycle assessment of fisheries: theory and application. J Clean Prod 73: 63-71.

Langlois J, Fréon P, Delgenes J.P, Steyer J.P, Hélias A (2015). Sea use impact category in life cycle assessment: characterization factors for life support functions. Int J Life Cycle Assess 20: 970-981.

Langlois J, Fréon P, Steyer J.P, Delgenès J.P, Hélias A (2015). Sea use impact category in life cycle assessment: characterization factors for life support functions. Int J Life Cycle Assess 20(7): 970-981. 
Laso J, Margallo M, Celaya J, Fullana P, Bala A, Gazulla C, Irabien A, Aldaco R (2016a). Waste management under a life cycle approach as a tool for a circular economy in the canned anchovy industry. Waste Manage Res 34 (8): 724-733.

Laso J, Margallo M, Fullana P, Bala A, Gazulla C, Irabien A, Aldaco R (2016b). Introducing life cycle thinking to define best available techniques for products: Application to the anchovy canning industry. J Clean Prod (In press). http://dx.doi.org/10.1016/j.jclepro.2016.08.040

Lorenzo-Toja Y, Vázquez-Rowe I, Chenel S, Marín-Navarro D, Moreira M.T, Feijoo G (2015). Eco-efficiency analysis of Spanish WWTPs using the LCA+DEA method. Water Res 68: 651-666.

Lovarelli D, Bacenetti J, Fiala M (2016). Water Footprint of crop productions: a review. Sci Total Environ 548549: 236-251.

Magrama (2013). Informe sobre el Estudio de Mercado de la Anchoa (Engraulis encrasicolus). Secretaría General de Pesca.

Margallo M, Aldaco R, Irabien A, Carrillo V, Fischer M, Bala A, Fullana P (2014). Life cycle assessment modelling of waste-to-energy incineration in Spain and Portugal. Waste Manage Res 32(6): 492-499.

Ministry of Agriculture, Food and Environment (2015). Dossier Autonómico de la Comunidad Autónoma de Cantabria. Análisis y Prospectiva-serie Territorial. Gobierno de España.

Nilsson P, Ziegler F (2007). Spatial distribution of fishing effort in relation to seafloor habitats in the Kattegat, a GIS analysis. Aquat Conserv 17: 421-440.

Niu R, Wang Z, Song Q, Li J (2012). LCA of scrap CRT display at various scenarios of treatment. Procedia Environmental Sciences, 16: 576-584.

Parker R (2011). Measuring and characterizing the ecological foot-print and life cycle environmental cost of Antartic Krill (Euphasia superb) products. M Sc Thesis. Dalhousie University, Canada.

Parker R, Tyedmers P (2012). Life cycle environmental impacts of three products derived from wild-caught Antarctic krill (Euphausia superba). Environ Sci Technol 46(9): 4958-4965.

Parker R, Tyedmers P (2015). Fuel consumption of global fishing fleets: current understanding and knowledge gaps. Fish and Fisheries 16: 684-696.

Parker RW, Hartmann K, Green BS, Gardner C, Watson RA (2015a). Environmental and economic dimensions of fuel use in Australian fisheries. J Clean Prod 87: 78-86.

Parker R, Vázquez-Rowe I, Tyedmers P (2015b). Fuel performance and carbon footprint of the global purse seine fleet. J Clean Prod 103: 517-524.

PAS 2050-2 (2012). Assessment of life cycle greenhouse gas emissions. Supplementary requirements for the application of PAS 2050:2011 to seafood and other aquatic food products.

Pauly D, Christensen V (1995). Primary production required to sustain global fisheries. Nature, 374(6519): 255257. 
Pelletier N, Ayer N, Tyedmers P, Kruse S, Flysjo A, Robillard G, Ziegler F, Scholz A, Sonesson U (2007). Impact Categories for Life Cycle Assessment Research of Seafood Production Systems: Review and Prospectus. Int $J$ Life Cycle Assess 12(6): 414-421.

Pelletier N, \& Tyedmers P. (2011). An ecological economic critique of the use of market information in life cycle assessment research. J. Ind. Ecol. 15(3): 342-354.

Plan de Residuos de Cantabria (2016). Plan de Residuos de la Comunidad Autónoma de Cantabria (2016-2022). Gobierno de Cantabria.

Pontes L.M, Ambrosio L, García M (2015). Cantabrian Sea purse seine anchovy fishery. Bureau Veritas Certification France. 1-174.

Ramos S, Vázquez-Rowe I, Artetxe I, Moreira M. T, Feijoo G, Zufía J (2011). Environmental assessment of the Atlantic mackerel (Scomber scombrus) season in the Basque Country. Increasing the timeline delimitation in fishery LCA studies. Int J Life Cycle Assess 16(7): 599-610.

Rosenbaum R.K, Bachmann T.M, Gold L.S, Huijbregts M.A.J, Jolliet O, Juraske R, Koehler A, Larsen H.F, MacLeod M, Margni M.D, McKone T.E, Payet J, Schuhmacher M, van de Meent D, Hauschild M.Z (2008). USEtox - The UNEP-SETAC toxicity model: Recommended characterisation factors for human toxicity and freshwater ecotoxicity in life cycle impact assessment. Int J Life Cycle Assess 13: 532-546.

Russell S.D, Alexander R.T (1996). The skipper effect debate: views from a Philippine fishery. J Anthropol Res 52(4): 433-460

Ruttan L, Tyedmers P (2007). Skippers, spotters and seiners: Analysis of the "skipper effect" in US menhaden (Brevoortia spp.) purse-seine fisheries. Fish Res 83: 73-80.

Song Q, Wang Z, Li J, Zeng X (2012). Life cycle assessment of TV sets in China: a case study of the impacts of CRT monitors. Waste Manage 32: 1926-1936.

Sthiannopkao S, Wong M.H (2013). Handling e-waste in developed and developing countries: Initiatives, practices, and consequences. Sci Total Enviro 463-464: 1147-1153.

SUPERPROP (2012). Superior Lifetime Operation Economy of Ship Propellers. Available at http://ec.europa.eu/research/transport/projects/items/superprop_en.htm.

Tyedmers P (2001). Energy consumed by North Atlantic fisheries. In Fisheries impacts on North Atlantic ecosystems: catch, effort, and national/regional datasets, vol. 9, ed. D. Zeller, R. Watson, and D. Pauly, 12-34 Fisheries Centre Research Reports.

Tyedmers P, Watson R, Pauly D (2005). Fueling global fishing fleets. Ambio, 34: 635-638.

Vázquez-Rowe I, Reyna J, García-Torres S, Kahhat R (2015) Is climate change-centrism an optimal policy making strategy to set national electricity mixes? Appl Energ 159: 108-116.

Vázquez-Rowe I, Tyedmers P (2013). Identify the importance of the “skipper effect” within sources of measured inefficiency in fisheries through data envelopment analysis (DEA). Mar Policy 38: 387-396. 
Vázquez-Rowe I, Moreira M.T, Feijoo G (2010). Life cycle assessment of horse mackerel fisheries in Galicia (NW Spain): Comparative analysis of two major fishing methods. Fish Res 106 (3): 517-527.

Vázquez-Rowe I, Moreira M.T, Feijoo G (2011b). Estimating global discards and their potential reduction for the Galician fishing fleet (NW Spain). Mar Policy 35: 140-147.

Vázquez-Rowe I, Moreira M.T, Feijoo G (2011a). Life Cycle Assessment of fresh hake fillets captured by the Galician fleet in the Northern Stock. Fish Res 1110: 128-135.

Vázquez-Rowe I, Moreira M.T, Feijoo G (2012a). Inclusion of discard assessment indicators in fisheries life cycle assessment studies. Expanding the use of fishery-specific impact categories. Int J Life Cycle Assess 17: 535-549.

Vázquez-Rowe I, Moreira M.T, Feijoo G (2012b). Environmental assessment of frozen common octopus (Octopus vulgaris) captured by Spanish fishing vessels in the Mauritanian EEZ. Mar Policy, 36(1): 180-188.

Vázquez-Rowe I, Hospido A, Moreira M.T, Feijoo G (2012c). Best practices in life cycle assessment implementation in fisheries. Improving and broadening environmental assessment for seafood production systems. Trends Food Sci Tech 28: 116-131.

Vázquez-Rowe I, Villanueva-Rey P, Moreira M.T, Feijoo G (2014a). Edible Protein Energy Return on Investment Ratio (ep-EROI) for Spanish Seafood Products. Ambio, 43 (3): 381-394.

Vázquez-Rowe I, Villanueva-Rey P, Hospido A, Moreira M.T, Feijoo G (2014b). Life cycle assessment of European pilchard (Sardina pilchardus) consumption. A case study for Galicia (NW Spain). Sci Total Environ 475: 48-60.

Vázquez-Rowe I, Kahhat R, Quispe I, Bentín M (2016). Environmental profile of green asparagus production in a hyper-arid zone in coastal Peru. J Clean Prod 112 (4): 2505-2517.

Villamor B, Abaunza P (2009). La anchoa del golfo de Vizcaya: un recurso pesquero en crisis. Perspectivas científicas. Anuario de la Naturaleza de Cantabria 6: 10-12.

Woods J.S, Veltman K, Huijbregts M.A, Verones F, Hertwich E.G (2016). Towards a meaningful assessment of marine ecological impacts in life cycle assessment (LCA). Environ Int 89: 48-61.

WULCA (2016). Consensual Method Development. Available at: http://www.wulca-waterlca.org/project.html. Last accessed: October $17^{\text {th }} 2016$.

Xunta de Galicia (2016). Pesca de Galicia. http://www.pescadegalicia.gal/. Last accessed: June 2016

Ziegler F, Hornborg S, Green B.S, Eigaard O.R, Farmery A.K, Hammar L, Hartmann K, Molander S, Parker R.W.R, Hognes E.S, Vázquez-Rowe I, Smith A.D.M (2016). Expanding the concept of sustainable seafood using Life Cycle Assessment. Fish and-Fisheries 17: 1073-1093.

Ziegler F, Valentinsson D (2008). Environmental life cycle assessment of Norway lobster (Nephrops novegicus) caught along the Swedish west coast by creels and conventional trawls-LCA methodology with case study. Int $J$ Life Cycle Asses 13: 487-497.

Ziegler F, Hornborg S (2014) Stock size matters more than vessel size: The fuel efficiency of Swedish demersal trawl fisheries 2002-2010. Mar Policy 44: 72-81 
Ziegler F, Winther U, Hognes E, Emanuelsson A, Sund V, Ellingsen H (2013). The carbon footprint of Norwegian seafood products on the global seafood markets. J Ind Ecol 17 (1): 103-116.

Zlatanos S, Laskaridis K (2007). Seasonal variation in the fatty acid composition of three Mediterranean fish sardine (Sardina pilchardus), anchovy (Engraulis encrasicolus) and picarel (Spicara smaris).Food Chem 103: $725-728$.

Zlatanos S, Sagredos A.N (1993). The fatty acids composition of some important Mediterranean fish species. Eur J Lipid Sci Tech 95 (2): 66-69. 